Review

\title{
Diagnostic Value of Choline PET in the Preoperative Localization of Hyperfunctioning Parathyroid Gland(s): A Comprehensive Overview
}

\author{
Cristina Ferrari ${ }^{1}{ }^{\mathbb{D}}$, Giulia Santo ${ }^{1} \mathbb{D}$, Paolo Mammucci ${ }^{1}$, Antonio Rosario Pisani ${ }^{1}$, Angela Sardaro ${ }^{2, *}$ \\ and Giuseppe Rubini ${ }^{1}$ \\ 1 Nuclear Medicine Unit, Interdisciplinary Department of Medicine, University of Bari Aldo Moro, \\ Piazza Giulio Cesare 11, 70124 Bari, Italy; ferrari_cristina@inwind.it (C.F.); giuliasanto92@gmail.com (G.S.); \\ paolo.mammucci@outlook.com (P.M.); apisani71@libero.it (A.R.P.); giuseppe.rubini@uniba.it (G.R.) \\ 2 Section of Radiology and Radiation Oncology, Interdisciplinary Department of Medicine, \\ University of Bari Aldo Moro, Piazza Giulio Cesare 11, 70124 Bari, Italy \\ * Correspondence: angela.sardaro@uniba.it
}

check for

updates

Citation: Ferrari, C.; Santo, G.; Mammucci, P.; Pisani, A.R.; Sardaro, A.; Rubini, G. Diagnostic Value of Choline PET in the Preoperative Localization of Hyperfunctioning Parathyroid Gland(s): A Comprehensive Overview. Biomedicines 2021, 9, 231. https:// doi.org/10.3390/biomedicines9030231

Academic Editor: Francesco Ceci

Received: 12 January 2021

Accepted: 18 February 2021

Published: 25 February 2021

Publisher's Note: MDPI stays neutral with regard to jurisdictional claims in published maps and institutional affiliations.

Copyright: (c) 2021 by the authors. Licensee MDPI, Basel, Switzerland. This article is an open access article distributed under the terms and conditions of the Creative Commons Attribution (CC BY) license (https:/ / creativecommons.org/licenses/by/ $4.0 /)$.
Abstract: Hyperparathyroidism is a metabolic disorder characterized by the excessive production of the parathyroid hormone. The diagnosis is based on clinical and laboratory data. In most cases the only treatment is surgery and a correct preoperatory localization of the hyperfunctioning parathyroid gland(s) is essential. Currently, ultrasonography combined with [ ${ }^{99 \mathrm{~m}} \mathrm{Tc}$ ]Tc-MIBI parathyroid scintigraphy, optionally associated with single photon emission computed tomography/computed tomography (SPECT/CT), represent the standard preoperative imaging. In recent years, a number of studies have evaluated the potential role of choline positron emission tomography (PET) in hyperparathyroidism with promising results. Most of the recent evidence underlined its higher sensitivity and diagnostic accuracy in the localization of hyperfunctioning parathyroid glands. Choline PET has a higher spatial resolution that is useful for the detection of smaller parathyroid glands and it also has shorter examination times and favorable radiation exposure. These are just a few of the aspects that support it to overcome traditional imaging. Moreover, from the preliminary data, the choline uptake mechanism seems to also have an impact on its better performance. For these reasons, if first used as second level imaging in patients with negative or inconclusive traditional imaging results, several authors have supported its use as a first line investigation. This comprehensive overview aims to provide an accurate description of the preliminary results available in the literature about the use of choline PET/CT in hyperparathyroidism and to compare these results with the performance of traditional imaging methods.

Keywords: hyperparathyroidism; $\left[{ }^{99 \mathrm{~m}} \mathrm{Tc}\right] \mathrm{Tc}-\mathrm{MIBI} ;\left[{ }^{18} \mathrm{~F}\right] \mathrm{FCH}$; choline; positron emission tomography; $\mathrm{PET} / \mathrm{CT}$

\section{Introduction}

Hyperparathyroidism (HPT) is the third most common endocrine disorder and is characterized by elevated or inappropriately normal parathyroid hormone (PTH) secretion, which regulates calcium and phosphorus metabolism [1].

This disorder is classified into three subgroups according to the pathogenesis. Primary HPT is the most common form, caused by a solitary parathyroid adenoma (80\%), followed by four gland hyperplasia (10-15\%), multiple adenomas (5\%) and parathyroid cancer $(<1 \%)$ [2]. HPT can also be due to an alteration of calcium homeostasis, frequently associated with a chronic disease that induces the overproduction of PTH. This condition, known as secondary HPT, can evolve into a tertiary form where one or more parathyroid glands begin to produce PTH independently.

In most cases, surgery is the only curative treatment and the correct presurgical detection of the hyperfunctioning parathyroid gland(s) represents a crucial step for patient management. 
The most commonly presurgical imaging assessment used is a combination of neck ultrasonography (US) and parathyroid scintigraphy with [ $\left.{ }^{99 \mathrm{~m}} \mathrm{Tc}\right] \mathrm{Tc}-\mathrm{MIBI}[3,4]$. Different scintigraphic protocols can be used such as the single-tracer ([ $\left.\left.{ }^{99 \mathrm{~m}} \mathrm{Tc}\right] \mathrm{Tc}-\mathrm{MIBI}\right)$, the dualphase/dual-tracer subtraction protocol $\left(\left[{ }^{99 \mathrm{~m}} \mathrm{Tc}\right] \mathrm{Tc}-\mathrm{MIBI}+\left[{ }^{99 \mathrm{~m}} \mathrm{Tc}\right] \mathrm{TcO}^{4-}\right.$ (pertechnetate) or $\left[{ }^{99 m} \mathrm{Tc}\right] \mathrm{Tc}-\mathrm{MIBI}+\left[{ }^{123} \mathrm{I}\right]$ Iodine) optionally integrated with single photon emission computed tomography (SPECT) or SPECT/computed tomography (CT) acquisition [5-7].

However, both of these methods have a few limitations. Low PTH serum levels and ionized calcium, a small adenoma, multiglandular disease and/or concomitant thyroid disease represent some factors associated with a lower scintigraphy performance [8]. Similarly, neck US is highly operator dependent and, in a few cases, is not able to differentiate parathyroid adenomas from reactive cervical lymph nodes as well as to detect ectopic parathyroid glands located in the upper mediastinum [5,7].

Recently, based on occasional findings, the role of positron emission tomography/CT (PET/CT) using choline-labeled radiopharmaceuticals has been highlighted [9].

The rationale of the use of choline-labeled radiopharmaceuticals in this setting of patients could be explained by the different mechanism of the uptake of parathyroid cells compared with [ $\left.{ }^{99 \mathrm{~m}} \mathrm{Tc}\right] \mathrm{Tc}-\mathrm{MIBI}$.

Of note, the parathyroid gland has two major types of cells, chief and oxyphilic cells. Chief cells are small with a big nucleus and poor cytoplasm and are responsible for PTH secretion in which also choline-kinase, a phospholipid/ $\mathrm{Ca}^{2 \pm}$ dependent enzyme, seems to play a role. Oxyphilic cells are characterized by an abundant typically acidophilic cytoplasm due to large amounts of mitochondria [10].

While it is well established that $\left[{ }^{99 \mathrm{~m}} \mathrm{Tc}\right] \mathrm{Tc}-\mathrm{MIBI}$, a lipophilic cation, concentrates in the mitochondria of parathyroid cells through the transmembrane electrical potential, the exact biological process underlying the choline uptake in HPT is not yet clearly understood.

Similar to [ $\left.{ }^{99 \mathrm{~m}} \mathrm{Tc}\right] \mathrm{Tc}-\mathrm{MIBI}$, thanks to its positive electric charge, choline-labeled radiopharmaceuticals enter through a membrane transporter and accumulate in the mitochondria of both oxyphilic and chief cells. Furthermore, in the chief cells, choline is also phosphorylated by choline-kinase, which is overexpressed in patients with HPT, and used as a component of cell membranes [11-14].

Therefore, if [ $\left.{ }^{99 \mathrm{~m}} \mathrm{Tc}\right] \mathrm{Tc}-\mathrm{MIBI}$ metabolism depends only on the mitochondria uptake, choline-labeled radiopharmaceuticals can exploit a double uptake mechanism that could represent the advantage of choline-PET to [ ${ }^{99 \mathrm{~m}} \mathrm{Tc}$ ]Tc-MIBI scintigraphy [15].

The aim of this review is to provide an accurate description of the preliminary results available in the literature about the use of choline PET/CT in HPT and to compare these results with the performance of traditional imaging methods.

The different mechanism uptake of both radiotracers in hyperfunctioning parathyroid cells is represented in Figure 1. 


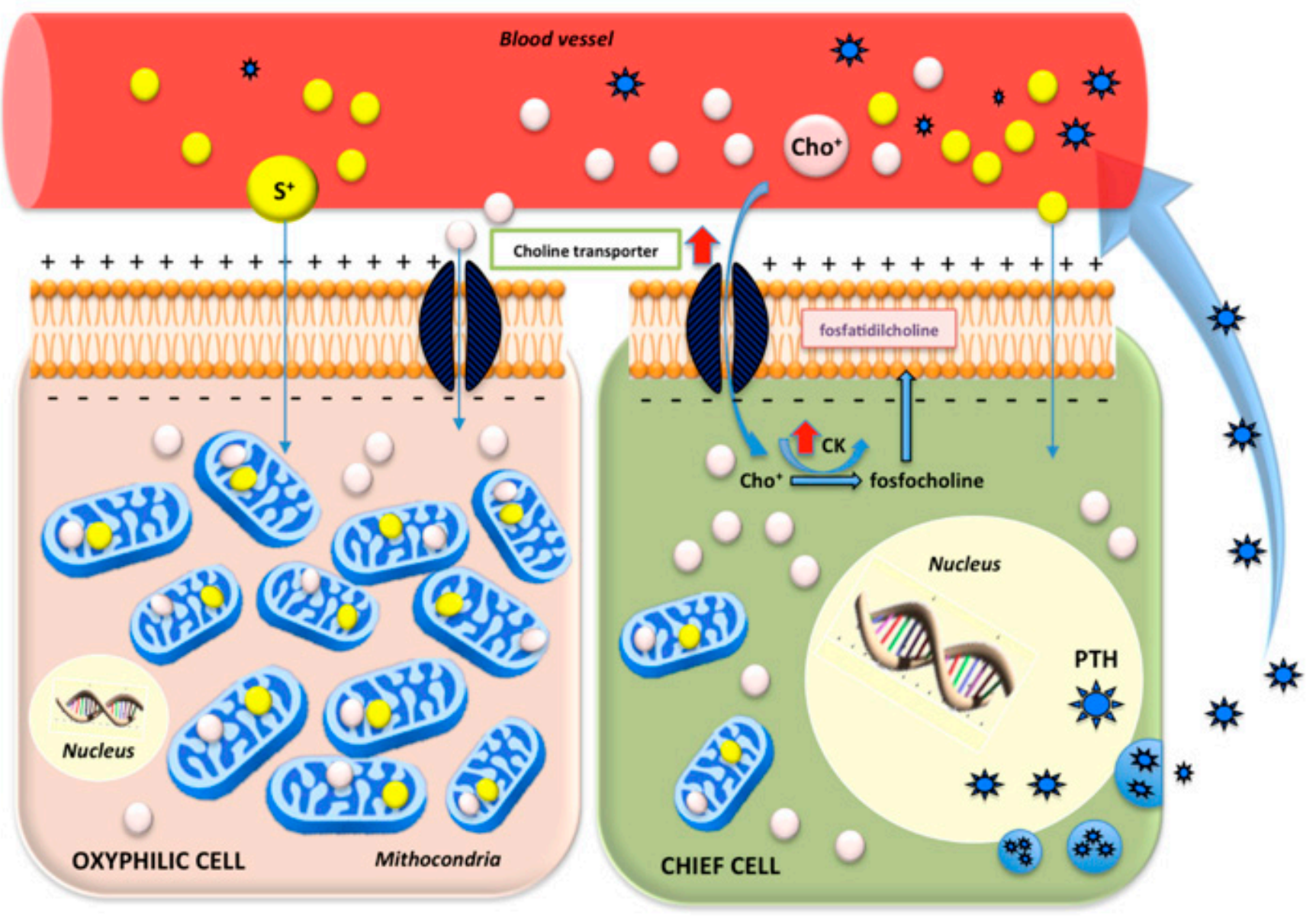

Figure 1. Schematic representation of the dual choline uptake mechanism by chief and oxyphilic cells. Thanks to its positive electric charge, choline enters the parathyroid cells through a membrane transporter, accumulating in both the oxyphilic and chief cells. Furthermore, internalized by chief cells thanks to a transmembrane protein, choline is phosphorylated through choline-kinase and then converted to phosphatidylcholine (lecithin), a necessary component of the cell membrane. The proposal mechanism in hyperparathyroidism (HPT) patients could be explained by an increased intracellular transport and an up-regulation of choline-kinase. The cation [ $\left.{ }^{99 \mathrm{~m}} \mathrm{Tc}\right] \mathrm{Tc}-\mathrm{MIBI}$ enters in both parathyroid cells and accumulates in the mitochondria. $\mathrm{S}^{+}$: [99mTc]Tc-MIBI; Cho ${ }^{+}$: choline; CK: choline-kinase; PTH: parathyroid hormone.

\section{Materials and Methods}

A bibliographic literature search until 30 November 2020 was conducted on three electronic databases (Pubmed, Scopus, Google Scholar). Based on a PICO (Problem/Population, Intervention, Comparison, Outcome) strategy search the following keywords were entered: (Hyperparathyroidism AND hyperfunctioning parathyroid glands AND/OR adenoma) and $\left(\left[{ }^{18} \mathrm{~F}\right] \mathrm{FCH}\right.$ PET $/ \mathrm{CT}$ OR $\left[{ }^{18} \mathrm{~F}\right] \mathrm{FCH}$ PET OR $\left[{ }^{11} \mathrm{C}\right]$ Choline PET /CT AND choline positron emission tomography) and ([99m $\mathrm{Tc}] \mathrm{Tc}-\mathrm{MIBI}$ AND parathyroid scintigraphy) and (diagnostic performance AND detection rate AND sensitivity AND specificity). Only original articles edited in English and about humans only that analyzed the role of $\left[{ }^{11} \mathrm{C} /{ }^{18} \mathrm{~F}\right]$ cholinelabeled radiopharmaceuticals in the localization of hyperfunctioning parathyroid gland(s) were finally included in this review. Articles with a sample size $<10$ patients, review, meta-analysis, case report or case series were not included in the discussion. To identify supplementary eligible articles, additional references were searched from the retrieved review articles. 


\section{Literature Results}

The literature search revealed 62 articles. Thirty of them were excluded after reviewing titles, abstracts and full texts. Therefore, 32 studies were considered suitable for the analysis: 14 studies were retrospective whereas 18 studies were prospective. In 28 studies choline was labeled with Fluorine-18 $\left[{ }^{18} \mathrm{~F}\right]$ while only four studies evaluated HPT with Carbon$11\left[{ }^{11} \mathrm{C}\right]$ choline. Most authors (84\%) examined the role of choline in primary HPT, in particular in the detection of parathyroid adenoma. Only $16 \%$ of authors included patients with secondary and/or tertiary HPT. In 25 studies choline PET/CT was compared with $\left[{ }^{99 \mathrm{~m}} \mathrm{Tc}\right] \mathrm{Tc}-\mathrm{MIBI}$ scintigraphy. In the articles where sensitivity, specificity, positive predictive value (PPV), negative predictive value (NPV) and overall accuracy were calculated, postsurgical histological examinations and/or the biochemical resolution of HPT after surgery were considered as the gold standard.

The characteristics of the included studies are detailed in Table 1. 
Table 1. Characteristics of the original articles reviewed.

\begin{tabular}{|c|c|c|c|c|c|c|c|c|c|c|}
\hline Year & Isotope & $\begin{array}{l}\text { Authors' } \\
\text { PMID }\end{array}$ & $\begin{array}{l}\text { Study } \\
\text { Type }\end{array}$ & Pts & Dose (MBq) & $\begin{array}{l}\text { Time p.i. } \\
\text { (min) }\end{array}$ & $\begin{array}{l}\text { Field of View } \\
\text { (FOV) }\end{array}$ & $\begin{array}{c}\text { Scintigraphic } \\
\text { Protocol }\end{array}$ & Performance & Main Findings \\
\hline 2014 & ${ }^{18} \mathrm{~F}$ & $\begin{array}{l}\text { Lezaic et al. [16] } \\
25063039\end{array}$ & $\mathrm{P}$ & 24 & 100 & $\begin{array}{c}5 \\
60\end{array}$ & $\begin{array}{l}\text { Neck and upper } \\
\text { mediastinum }\end{array}$ & ALL & $\begin{array}{l}\text { Sensitivity, } \\
\text { specificity, } \\
\text { PPV, NPV }\end{array}$ & $\begin{array}{c}\text { PTA: }\left[{ }^{18} \mathrm{~F}\right] \mathrm{FCH} \text { PET } / \mathrm{CT} \text { sensitivity } 94 \% \text {; } \\
\text { specificity } 100 \% \text {. Multiple parathyroid } \\
\text { lesions: }\left[{ }^{18} \mathrm{~F}\right] \mathrm{FCH} \text { PET/CT sensitivity } \\
\text { 91\% (vs. conventional imaging, } 50 \% \text { ). }\end{array}$ \\
\hline 2014 & ${ }^{18} \mathrm{~F}$ & $\begin{array}{c}\text { Michaud et al. [17] } \\
26469908\end{array}$ & $\mathrm{P}$ & 12 & $3 / \mathrm{kg}$ & Dynamic & $\begin{array}{l}\text { From the skull to } \\
\text { mid thighs (men) } \\
\text { or to liver } \\
\text { (women) }\end{array}$ & $\begin{array}{l}\text { Dual-tracer/dual- } \\
\text { phase } \\
\text { SPECT/CT }\end{array}$ & Sensitivity, DR & $\begin{array}{l}\text { On a per lesion level, }\left[{ }^{18} \mathrm{~F}\right] \mathrm{FCH} \text { PET/CT } \\
\text { sensitivity was } 89 \% \text {. On a per patient level, } \\
\text { the DR of }\left[{ }^{18} \mathrm{~F}\right] \mathrm{FCH} \text { PET/CT was } 92 \% \text {. }\end{array}$ \\
\hline 2014 & ${ }^{11} \mathrm{C}$ & $\begin{array}{l}\text { Orevi et al. [18] } \\
\quad 25290292\end{array}$ & $\mathrm{P}$ & 40 & 370 & Dynamic & $\begin{array}{l}\text { Middle ear } \\
\text { to diaphragm }\end{array}$ & $\begin{array}{l}\text { Dual-tracer/dual- } \\
\text { phase } \\
\text { SPECT/CT }\end{array}$ & $\begin{array}{l}\text { SUVmax } \\
\text { SUVratio } \\
\text { sensitivity }\end{array}$ & $\begin{array}{l}\text { Lesions SUVmax ranged from } 2.1 \text { up to } \\
\text { 31. The SUVratio ranged from } 0.85 \text { to } \\
\left.\text { 4.31. }{ }^{11} \mathrm{C}\right] \text { Choline yielded a sensitivity } \\
\text { of } 92.3 \% \text { compared with } 88.5 \% \text { of } \\
\left.\text { [ }{ }^{99 \mathrm{~m}} \mathrm{Tc}\right] \mathrm{Tc}-\mathrm{MIBI} \text {. }\end{array}$ \\
\hline 2015 & ${ }^{18} \mathrm{~F}$ & $\begin{array}{c}\text { Rep et al. [19] } \\
26834518\end{array}$ & $\mathrm{P}$ & 43 & 100 & $\begin{array}{c}5 \\
60 \\
120\end{array}$ & $\begin{array}{l}\text { Neck and upper } \\
\text { mediastinum }\end{array}$ & 1 & $\begin{array}{l}\text { Sensitivity, } \\
\text { specificity, } \\
\text { PPV, NPV, } \\
\text { accuracy, } \\
\text { SUVmax, } \\
\text { SUVratio }\end{array}$ & $\begin{array}{l}\text { Accumulation of }\left[{ }^{18} \mathrm{~F}\right] \mathrm{FCH} \text { PET } / \mathrm{CT} \text { was } \\
\text { higher in parathyroid lesions in } \\
\text { comparison with the thyroid tissue with } \\
\text { a significantly higher SUVmean in the } \\
\text { second ( } 60 \text { min) and in the third } \\
\text { (120 min) phase, with a better contrast } \\
\text { lesions/thyroid tissue in the second and } \\
\text { the third phase. }\end{array}$ \\
\hline 2016 & ${ }^{18} \mathrm{~F}$ & $\begin{array}{l}\text { Kluijfhout et al. [20] } \\
27612033\end{array}$ & $\mathrm{R}$ & 44 & $2 / \mathrm{kg}$ & 30 & $\begin{array}{l}\text { From the base of } \\
\text { the skull to the } \\
\text { mediastinum }\end{array}$ & $\begin{array}{l}\text { Dual-tracer/dual- } \\
\text { phase } \\
\text { SPECT/CT }\end{array}$ & $\begin{array}{l}\text { DR, sensitivity, } \\
\text { PPV, SUVratio }\end{array}$ & $\begin{array}{l}\left.{ }^{18} \mathrm{~F}\right] \mathrm{FCH} \text { PET/CT was positive in } 34 / 44 \\
(77.3 \%) \text { cases. In patients who } \\
\text { underwent surgery (33), }\left[{ }^{18} \mathrm{~F}\right] \mathrm{FCH} \\
\text { PET/CT showed a sensitivity } 94.3 \% \text { (vs. } \\
\left.30 \% \text { of }\left[{ }^{99 \mathrm{~m}} \mathrm{Tc}\right] \mathrm{Tc}-\mathrm{MIBI}\right) \text { and a PPV of } \\
97.1 \% \text { (vs. } 69.2 \%) \text {. The mean SUVmax of } \\
\text { the } 33 \text { preoperatively identified } \\
\text { pathological glands was } 5.2 \text {, which was } \\
\text { significantly higher than the } 2.9 \mathrm{SUV} \text { of } \\
\text { the thyroid. }\end{array}$ \\
\hline
\end{tabular}


Table 1. Cont.

\begin{tabular}{|c|c|c|c|c|c|c|c|c|c|c|}
\hline Year & Isotope & $\begin{array}{l}\text { Authors' } \\
\text { PMID }\end{array}$ & $\begin{array}{l}\text { Study } \\
\text { Type }\end{array}$ & Pts & Dose (MBq) & $\begin{array}{l}\text { Time p.i. } \\
\text { (min) }\end{array}$ & $\begin{array}{l}\text { Field of View } \\
\text { (FOV) }\end{array}$ & $\begin{array}{l}\text { Scintigraphic } \\
\text { Protocol }\end{array}$ & Performance & Main Findings \\
\hline 2016 & ${ }^{18} \mathrm{~F}$ & $\begin{array}{l}\text { Michaud et al. [21] } \\
26469908\end{array}$ & $\mathrm{P}$ & 17 & $3 / \mathrm{kg}$ & $\begin{array}{l}\text { Dynamic } \\
10\end{array}$ & $\begin{array}{l}\text { From the skull to } \\
\text { mid thighs (men) } \\
\text { or to liver } \\
\text { (women) }\end{array}$ & $\begin{array}{c}\text { Dual-tracer/dual- } \\
\text { phase } \\
\text { SPECT/CT }\end{array}$ & $\begin{array}{l}\text { Sensitivity } \\
\text { specificity } \\
\text { SUVmax } \\
\text { SUVratio }\end{array}$ & $\begin{array}{l}\text { Per patient-based, the scintigraphy } \\
\text { sensitivity was } 69 \% \text { by open and } 94 \% \text { by } \\
\left.\text { masked reading and [ }{ }^{18} \mathrm{~F}\right] \mathrm{FCH} \text { PET } / \mathrm{CT} \\
\text { sensitivity was } 88 \% \text { by open and } 94 \% \text { by } \\
\text { masked reading. Per lesion-based, the } \\
\text { scintigraphy sensitivity was } 58 \% \text { by } \\
\text { open and } 83 \% \text { by masked reading and } \\
{\left[{ }^{18} \mathrm{~F}\right] \mathrm{FCH} \text { PET } / \mathrm{CT} \text { sensitivity } 88 \% \text { by }} \\
\text { open and } 96 \% \text { by masked reading. }\end{array}$ \\
\hline 2017 & ${ }^{18} \mathrm{~F}$ & $\begin{array}{l}\text { Thanseer et al. [22] } \\
28902729\end{array}$ & $\mathrm{P}$ & 54 & 150-185 & $10-15 ; 60$ & 1 & $\begin{array}{l}\text { Dual-phase } \\
\text { SPECT/CT }\end{array}$ & $\begin{array}{l}\text { Sensitivity, } \\
\text { PPV, accuracy }\end{array}$ & $\begin{array}{c}{\left[{ }^{18} \mathrm{~F}\right] \mathrm{FCH} \text { PET } / \mathrm{CT} \text { showed } 100 \%} \\
\text { sensitivity, } 96.3 \% \text { PPV and } 96.3 \% \text { accuracy } \\
\text { in localizing parathyroid adenomas } \\
\text { regardless of the location (eutopic or } \\
\text { ectopic) on patient-wise analysis. In the } \\
\text { lesion-wise analysis of } 56 \text { lesions, } \\
{\left[{ }^{18} \mathrm{~F}\right] \mathrm{FCH} \text { PET } / \mathrm{CT} \text { revealed } 100 \%} \\
\text { sensitivity, } 92.8 \% \text { PPV and } 92.8 \% \text { accuracy. }\end{array}$ \\
\hline 2017 & ${ }^{18} \mathrm{~F}$ & $\begin{array}{l}\text { Hocevar et al. [23] } \\
\quad 27776943\end{array}$ & $\mathrm{R}$ & 15 & 100 & $5 ; 60$ & $\begin{array}{l}\text { Neck and upper } \\
\text { mediastinum }\end{array}$ & $\begin{array}{l}\text { Dual-phase } \\
\text { SPECT/CT }\end{array}$ & PPV & $\begin{array}{l}{\left[{ }^{18} \mathrm{~F}\right] \mathrm{FCH} \text { PET /CT showed a PPV of }} \\
95.2 \% \text { according to the histology. }\end{array}$ \\
\hline 2017 & ${ }^{18} \mathrm{~F}$ & $\begin{array}{l}\text { Kluijfhout et al. [24] } \\
\qquad 28121522\end{array}$ & $\mathrm{P}$ & 10 & $188 \pm 26$ & $\begin{array}{l}\text { Dynamic } \\
10\end{array}$ & $\begin{array}{l}\text { From the base of } \\
\text { the skull to the } \\
\text { mediastinum }\end{array}$ & $\begin{array}{c}\text { Dual-tracer/dual- } \\
\text { phase } \\
\text { SPECT/CT }\end{array}$ & $\begin{array}{l}\text { Sensitivity, } \\
\text { PPV, } \\
\text { SUVratio }\end{array}$ & $\begin{array}{l}{\left[{ }^{18} \mathrm{~F}\right] \mathrm{FCH} \text { PET } / \mathrm{MR} \text { reached } 90 \%} \\
\text { sensitivity without any false positive } \\
\text { results (PPV: } 100 \% \text { ). The median } \\
\text { SUVmax was } 4.9 \text {, significantly higher } \\
\text { than the } 2.7 \text { of thyroid SUVmax } \\
\text { (SUVratio ranging from } 1.2 \text { to } 2.5 \text { ). }\end{array}$ \\
\hline 2018 & ${ }^{18} \mathrm{~F}$ & $\begin{array}{l}\text { Alharbi et al. [25] } \\
\qquad 29508264\end{array}$ & $\mathrm{R}$ & 52 & $150 \pm 12$ & $2 ; 50$ & $\begin{array}{l}\text { Top of the head to } \\
\text { the upper } \\
\text { abdomen }\end{array}$ & 1 & SUVmax & $\begin{array}{l}\text { The majority of adenomas }(71.1 \%) \\
\text { demonstrated an increase in SUVmax } \\
\text { from early to late phase. A positive } \\
\text { correlation was observed between } \\
\text { SUVmax in late phase and PTH level and } \\
\text { between ABR in late phase and PTH level. } \\
\text { The surgical specimen volume was } \\
\text { positively correlated with the PET/MR } \\
\text { volume and PTH level. }\end{array}$ \\
\hline
\end{tabular}


Table 1. Cont.

\begin{tabular}{|c|c|c|c|c|c|c|c|c|c|c|}
\hline Year & Isotope & $\begin{array}{l}\text { Authors' } \\
\text { PMID }\end{array}$ & $\begin{array}{l}\text { Study } \\
\text { Type }\end{array}$ & Pts & Dose (MBq) & $\begin{array}{l}\text { Time p.i. } \\
\text { (min) }\end{array}$ & $\begin{array}{l}\text { Field of View } \\
\text { (FOV) }\end{array}$ & $\begin{array}{c}\text { Scintigraphic } \\
\text { Protocol }\end{array}$ & Performance & Main Findings \\
\hline 2018 & ${ }^{18} \mathrm{~F}$ & $\begin{array}{c}\text { Rep et al. [26] } \\
29339573\end{array}$ & $\mathrm{P}$ & 36 & 100 & $5 ; 60$ & $\begin{array}{l}\text { Neck and upper } \\
\text { mediastinum }\end{array}$ & $\begin{array}{l}\text { Dual-phase } \\
\text { SPECT/CT }\end{array}$ & $\begin{array}{c}\text { Sensitivity, } \\
\text { specificity, ED }\end{array}$ & $\begin{array}{l}\text { PSS: sensitivity } 46 \% \text { and specificity } 98 \% \text {. } \\
\text { [99m Tc]Tc-MIBI SPECT /CT sensitivity } \\
64 \% \text { and specificity } 96 \% \text {. }\left[{ }^{18} \mathrm{~F}\right] \mathrm{FCH} \\
\text { PET/CT sensitivity } 97 \% \text { and specificity } \\
\text { 99\%. The ED after administration of the } \\
\text { RPH alone was highest for conventional } \\
\text { dual-tracer imaging followed by } \\
\left.\left[{ }^{99 \mathrm{~m}} \mathrm{Tc}\right] \mathrm{Tc}-\mathrm{MIBI} \text { alone (SPECT } / \mathrm{CT}\right) ; \text { it } \\
\text { was the lowest for }\left[{ }^{18} \mathrm{~F}\right] \mathrm{FCH} \text { (PET/CT). }\end{array}$ \\
\hline 2018 & ${ }^{18} \mathrm{~F}$ & $\begin{array}{l}\text { Araz et al. [13] } \\
\quad 30138157\end{array}$ & $\mathrm{P}$ & 35 & 100 & $45-60$ & 1 & $\begin{array}{l}\text { Dual-phase } \\
\text { SPECT/CT }\end{array}$ & $\begin{array}{l}\text { Sensitivity, } \\
\text { specificity, } \\
\text { PPV, NPV, } \\
\text { accuracy, } \\
\text { SUVmax }\end{array}$ & $\begin{array}{l}\text { The sensitivity, specificity, PPV, NPV and } \\
\text { accuracy were } 96,100,100,93 \text { and } 97 \% \text {, } \\
\text { for }\left[{ }^{18} \text { F]FCH PET/CT, respectively. }\right. \\
\text { The mean serum PTH levels were } \\
\text { significantly higher and lumbar and } \\
\text { femur T scores were significantly lower in } \\
\text { patients with an SUVmax greater than } 4.4 \text {. }\end{array}$ \\
\hline 2018 & ${ }^{18} \mathrm{~F}$ & $\begin{array}{l}\text { Grimaldi et al. [7] } \\
29680989\end{array}$ & $\mathrm{P}$ & 27 & 100 & 30 & 1 & $\begin{array}{l}\text { Dual-phase } \\
\text { SPECT/CT }\end{array}$ & $\begin{array}{l}\text { Sensitivity, } \\
\text { specificity, } \\
\text { PPV, NPV. }\end{array}$ & $\begin{array}{l}\text { In patients with HPT recurrence or with } \\
\text { a suspicion of multiple gland disease, } \\
{\left[{ }^{18} \mathrm{~F}\right] \mathrm{FCH} \text { PET } / \mathrm{CT} \text { showed a per patient }} \\
\text { sensitivity of } 81 \% \text {, PPV } 94 \% \text { and a per } \\
\text { gland sensitivity of } 76 \% \text {, PPV } 85 \% \text {, } \\
\text { specificity } 91 \% \text { and NPV } 86 \% .\end{array}$ \\
\hline 2018 & ${ }^{18} \mathrm{~F}$ & $\begin{array}{c}\text { Huber et al. [28] } \\
29372312\end{array}$ & $\mathrm{R}$ & 26 & $151 \pm 16$ & Dynamic & $\begin{array}{c}\text { From the vortex to } \\
\text { the upper } \\
\text { abdomen }\end{array}$ & $\begin{array}{l}\text { Dual-phase } \\
\text { SPECT/CT }\end{array}$ & $\begin{array}{l}\text { Sensitivity, } \\
\text { PPV }\end{array}$ & $\begin{array}{c}\text { FCH PET sensitivity was } 96.2 \% \text {, } \\
\text { PPV } 100 \% \text {. }\end{array}$ \\
\hline
\end{tabular}


Table 1. Cont

\begin{tabular}{|c|c|c|c|c|c|c|c|c|c|c|}
\hline Year & Isotope & $\begin{array}{l}\text { Authors' } \\
\text { PMID }\end{array}$ & $\begin{array}{l}\text { Study } \\
\text { Type }\end{array}$ & Pts & Dose (MBq) & $\begin{array}{l}\text { Time p.i. } \\
\text { (min) }\end{array}$ & $\begin{array}{l}\text { Field of View } \\
\text { (FOV) }\end{array}$ & $\begin{array}{l}\text { Scintigraphic } \\
\text { Protocol }\end{array}$ & Performance & Main Findings \\
\hline 2018 & ${ }^{18} \mathrm{~F}$ & $\begin{array}{l}\text { Quak et al. [29] } \\
29270788\end{array}$ & $\mathrm{P}$ & 25 & $1.5 / \mathrm{kg}$ & 60 & 1 & $\begin{array}{l}\text { Dual-phase } \\
\text { SPECT/CT }\end{array}$ & $\begin{array}{l}\text { SUVratio, } \\
\text { SUVmax, } \\
\text { sensitivity, } \\
\text { PPV }\end{array}$ & $\begin{array}{l}\text { On per lesion and per patient }\left[{ }^{18} \mathrm{~F}\right] \mathrm{FCH} \\
\text { PET/CT sensitivities of } 91.3 \% \text { and } 90.5 \% \text {, } \\
\text { respectively. On per lesion and per } \\
\text { patient PPV were } 87.5 \% \text { and } 86.4 \% \text {, } \\
\text { respectively. }\left[{ }^{18} \mathrm{~F}\right] \mathrm{FCH} \text { uptake in } \\
\text { adenomas was five and a half-fold } \\
\text { higher than surrounding muscle } \\
\text { background and three-fold higher than } \\
\text { thyroid uptake. }\end{array}$ \\
\hline 2018 & ${ }^{18} \mathrm{~F}$ & $\begin{array}{c}\text { Prabhu et al. [30] } \\
\quad 30379751\end{array}$ & $\mathrm{P}$ & 14 & $185-296$ & $\begin{array}{c}\text { Dynamic } \\
45-60\end{array}$ & $\begin{array}{l}\text { From the angle of } \\
\text { mandible to the } \\
\text { diaphragm }\end{array}$ & 1 & $\begin{array}{l}\text { A/T ratio; } \\
\text { LN/T ratio; } \\
\text { SUVmax }\end{array}$ & $\begin{array}{l}\text { A higher SUVmax was observed in } \\
\text { dynamic images compared with static } \\
\text { images. A/T ratio in the dynamic and } \\
\text { static images was comparable. The tracer } \\
\text { may be able to adequately differentiate } \\
\text { parathyroid adenoma from cervical LN: } \\
\text { the difference between mean A/T and } \\
\text { LN/T ratios in early dynamic imaging } \\
\text { was found to be significant. }\end{array}$ \\
\hline 2018 & ${ }^{18} \mathrm{~F}$ & $\begin{array}{c}\text { Zajíčková et al. [15] } \\
30484682\end{array}$ & $\mathrm{R}$ & 13 & $180 \pm 48$ & $30 \pm 20$ & $\begin{array}{l}\text { From the base of } \\
\text { the skull to the } \\
\text { mediastinum }\end{array}$ & $\begin{array}{c}\text { Dual-tracer/dual- } \\
\text { phase } \\
\text { SPECT/CT }\end{array}$ & $\begin{array}{l}\text { Sensitivity, } \\
\text { PPV }\end{array}$ & $\begin{array}{c}{\left[{ }^{18} \mathrm{~F}\right] \mathrm{FCH} \text { yielded a per patient }} \\
\text { sensitivity of } 92 \% \text {. The per patient PPV } \\
\text { of }\left[{ }^{18} \mathrm{~F}\right] \mathrm{FCH} \text { was } 100 \% \text {. The mean size of } \\
14 \text { resected parathyroid lesions was } \\
11.9 \mathrm{~mm} \text { with a per lesion sensitivity of } \\
93 \% \text { and per gland PPV of } 81 \% \text {. }\end{array}$ \\
\hline 2018 & ${ }^{18} \mathrm{~F}$ & $\begin{array}{c}\text { Beheshti et al. [11] } \\
29516131\end{array}$ & $\mathrm{P}$ & 82 & $3.2 / \mathrm{kg}$ & $\begin{array}{c}60 \\
\pm 100-120\end{array}$ & $\begin{array}{c}\text { From the base of } \\
\text { the skull to the } \\
\text { mediastinum }\end{array}$ & $\begin{array}{l}\text { Dual-phase } \\
\text { SPECT/CT }\end{array}$ & $\begin{array}{l}\text { DR, sensitivity, } \\
\text { specificity, } \\
\text { PPV, NPV, } \\
\text { accuracy }\end{array}$ & $\begin{array}{c}\text { DR: }\left[{ }^{18} \mathrm{~F}\right] \mathrm{FCH} \text { PET } / \mathrm{CT} 93 \% \text { vs. } \\
{\left[{ }^{99 \mathrm{~m}} \mathrm{Tc}\right] \mathrm{Tc}-\mathrm{MIBI} \text { SPECT } / \mathrm{CT} 61 \% \text {. }} \\
\text { The sensitivity, specificity, PPV, NPV and } \\
\text { overall accuracy of PET/CT were } 93.7 \% \text {, } \\
96.0 \%, 90.2 \%, 97.4 \% \text { and } 95.3 \% \text {, } \\
\text { respectively. Corresponding values for } \\
\left.\text { [ }{ }^{99 \mathrm{~m}} \mathrm{Tc}\right] \mathrm{Tc}-\mathrm{MIBI} \text { SPECT } / \mathrm{CT} \text { were } 60.8 \% \text {, } \\
\text { 98.5\%, } 94.1 \%, 86.3 \% \text { and } 87.7 \%, \\
\text { respectively. The sizes of the } \\
\text { parathyroid adenomas significantly } \\
\text { impacted on }\left[{ }^{99 \mathrm{~m}} \mathrm{Tc}\right] \mathrm{Tc}-\mathrm{MIBI} \text { SPECT } / \mathrm{CT} \text {. }\end{array}$ \\
\hline
\end{tabular}


Table 1. Cont.

\begin{tabular}{|c|c|c|c|c|c|c|c|c|c|c|}
\hline Year & Isotope & $\begin{array}{l}\text { Authors' } \\
\text { PMID }\end{array}$ & $\begin{array}{l}\text { Study } \\
\text { Type }\end{array}$ & Pts & Dose (MBq) & $\begin{array}{l}\text { Time p.i. } \\
\text { (min) }\end{array}$ & $\begin{array}{l}\text { Field of View } \\
\text { (FOV) }\end{array}$ & $\begin{array}{l}\text { Scintigraphic } \\
\text { Protocol }\end{array}$ & Performance & Main Findings \\
\hline 2019 & ${ }^{18} \mathrm{~F}$ & $\begin{array}{l}\text { Broos et al. [31] } \\
\quad 30877179\end{array}$ & $\mathrm{R}$ & 64 & 150 & $\begin{array}{c}5 \\
60\end{array}$ & $\begin{array}{l}\text { From the temporo- } \\
\text { mandibular joint } \\
\text { to the diaphragm }\end{array}$ & 1 & $\begin{array}{l}\text { SUVmax; } \\
\text { SUVpeak; } \\
\text { SUVratio }\end{array}$ & $\begin{array}{l}\text { There was a significant decrease in } \\
{\left[{ }^{18} \mathrm{~F}\right] \mathrm{FCH} \text { uptake in the glands on late }} \\
\text { versus early time-points but there was a } \\
\text { significant increase in the ratio of } \\
\text { parathyroid uptake to thyroid uptake. }\end{array}$ \\
\hline 2019 & ${ }^{18} \mathrm{~F}$ & $\begin{array}{l}\text { Piccardo et al. [32] } \\
\quad 30219964\end{array}$ & $\mathrm{P}$ & 44 & $2.5 / \mathrm{kg}$ & 10 & $\begin{array}{l}\text { From the upper } \\
\text { neck to abdomen }\end{array}$ & $\begin{array}{l}\text { Dual-tracer/dual- } \\
\text { phase } \\
\text { SPECT/CT }\end{array}$ & DR, sensitivity & $\begin{array}{l}{\left[{ }^{18} \mathrm{~F}\right] \mathrm{FCH} \text { PET } / 4 \mathrm{DCeCT} \text { detection rate }} \\
\text { was } 72.7 \% \text { and in surgically treated } \\
\text { patients the sensitivity was } 100 \% \text {. These } \\
\text { results were significantly better than } \\
\text { those of }\left[{ }^{18} \mathrm{~F}\right] \mathrm{FCH} \text { PET } / \mathrm{CT} \text { ( } 56.8 \% \text { and } \\
80 \% \text {, respectively) and those of } 4 \mathrm{DCeCT} \\
\text { (54.5 and } 74 \% \text {, respectively). }\end{array}$ \\
\hline 2019 & ${ }^{18} \mathrm{~F}$ & $\begin{array}{l}\text { Amadou et al. [33] } \\
\quad 30659347\end{array}$ & $\mathrm{R}$ & 29 & $231 \pm 42$ & 60 & 1 & $\begin{array}{l}\text { Dual-phase } \\
\text { SPECT/CT }\end{array}$ & $\begin{array}{l}\text { Sensitivity } \\
\text { specificity, } \\
\text { PPV, NPV }\end{array}$ & $\begin{array}{c}\text { On a per lesion analysis, sensitivity, } \\
\text { specificity, PPV and NPV values were, } \\
\text { respectively, } 96 \%, 13 \%, 77 \% \text { and } 50 \% \text { for } \\
{\left[{ }^{18} \mathrm{~F}\right] \mathrm{FCH} \text { PET } / \mathrm{CT} \text { and } 75 \%, 40 \%, 80 \%} \\
\text { and } 33 \% \text { for } 4 \mathrm{DCeCT} \text {. On a per patient } \\
\text { analysis, sensitivity was } 85 \% \text { for } \\
{\left[{ }^{18} \mathrm{~F}\right] \mathrm{FCH} \text { PET } / \mathrm{CT} \text { and } 63 \% \text { for } 4 \mathrm{DCeCT} \text {. }}\end{array}$ \\
\hline 2019 & ${ }^{11} \mathrm{C}$ & $\begin{array}{l}\text { Noltes et al. [34] } \\
\quad 31367792\end{array}$ & $\mathrm{R}$ & 21 & $6.3 \pm 1.2 / \mathrm{kg}$ & 20 & 1 & 1 & $\begin{array}{l}\text { SUVratio } \\
\text { SUVmax }\end{array}$ & $\begin{array}{l}\text { The A/T ratio became constant from the } \\
\text { uptake time of } 20-30 \text { min p.i. onwards. } \\
\text { In the uptake time of } 0-10 \text { vs. } 10-20 \text { min } \\
\text { p.i. the A/T ratio significantly increased } \\
\text { from } 1.49 \text { to } 1.65 \text {. }\end{array}$ \\
\hline 2019 & ${ }^{18} \mathrm{~F}$ & $\begin{array}{l}\text { Khafif et al. [35] } \\
\quad 30877424\end{array}$ & $\mathrm{P}$ & 19 & 100 & Dynamic & 1 & $\begin{array}{l}\text { Dual-phase } \\
\text { SPECT/CT }\end{array}$ & Sensitivity & $\begin{array}{l}{\left[{ }^{18} \mathrm{~F}\right] \mathrm{FCH} \text { PET } / \mathrm{MR} \text { showed a sensitivity }} \\
\text { of } 84.2 \% \text { and predicted the side of the } \\
\text { disease gland in } 100 \% \text { of cases. }\end{array}$ \\
\hline 2019 & ${ }^{18} \mathrm{~F}$ & $\begin{array}{c}\text { Xue et al. [36] } \\
31879808\end{array}$ & $\mathrm{P}$ & 17 & $111-185$ & $\begin{array}{l}10 \\
60\end{array}$ & $\begin{array}{l}\text { Neck and upper } \\
\text { mediastinum }\end{array}$ & $\begin{array}{l}\text { Dual-tracer/dual- } \\
\text { phase } \\
\text { SPECT/CT }\end{array}$ & $\begin{array}{l}\text { Sensitivity, } \\
\text { specificity, } \\
\text { PPV, NPV, } \\
\text { accuracy }\end{array}$ & $\begin{array}{c}\text { In patients with uremic } \\
\text { hyperparathyroidism }\left[{ }^{18} \mathrm{~F}\right] \mathrm{FCH} \text { PET/CT } \\
\text { showed a sensitivity, specificity, } \\
\text { accuracy, PPV and NPV of } 84.13 \%, 100 \% \text {, } \\
86.49 \%, 100 \% \text { and } 52.38 \% \text {, respectively. }\end{array}$ \\
\hline
\end{tabular}


Table 1. Cont.

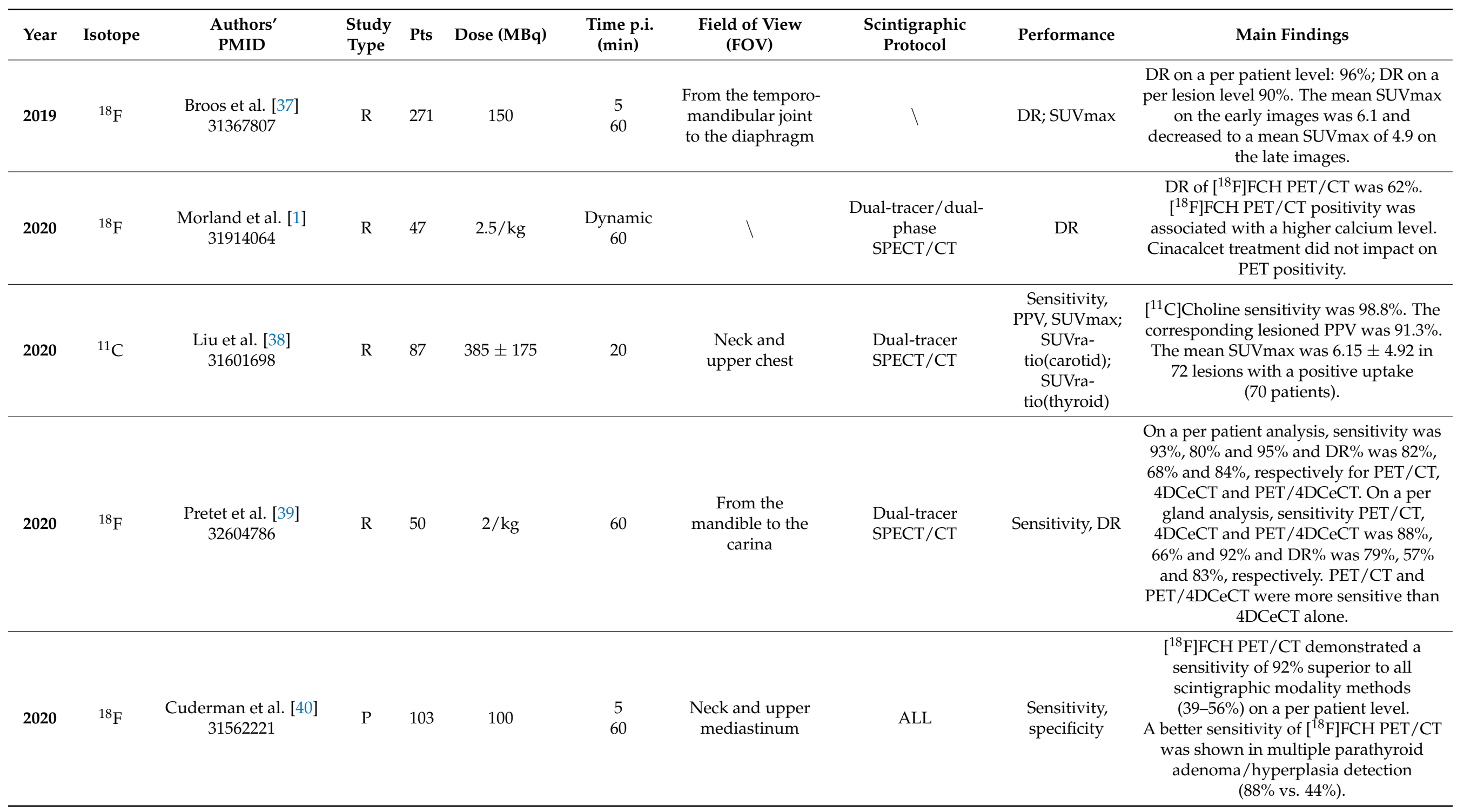


Table 1. Cont.

\begin{tabular}{|c|c|c|c|c|c|c|c|c|c|c|}
\hline Year & Isotope & $\begin{array}{l}\text { Authors' } \\
\text { PMID }\end{array}$ & $\begin{array}{l}\text { Study } \\
\text { Type }\end{array}$ & Pts & Dose (MBq) & $\begin{array}{l}\text { Time p.i. } \\
\text { (min) }\end{array}$ & $\begin{array}{l}\text { Field of View } \\
\text { (FOV) }\end{array}$ & $\begin{array}{l}\text { Scintigraphic } \\
\text { Protocol }\end{array}$ & Performance & Main Findings \\
\hline 2020 & ${ }^{18} \mathrm{~F}$ & $\begin{array}{c}\text { Uslu-Beşli et al. [41] } \\
31997599\end{array}$ & $\mathrm{R}$ & 105 & $325.1 \pm 86.7$ & $\begin{array}{l}15 \\
45\end{array}$ & $\begin{array}{l}\text { Neck and upper } \\
\text { chest (15 min); } \\
\text { whole body (45 } \\
\text { min) }\end{array}$ & $\begin{array}{l}\text { Dual-phase } \\
\text { SPECT/CT }\end{array}$ & $\begin{array}{c}\text { Sensitivity, } \\
\text { PPV, accuracy }\end{array}$ & $\begin{array}{l}\text { Sensitivity, PPV and accuracy of } \\
{\left[{ }^{18} \mathrm{~F}\right] \mathrm{FCH} \text { PET } / \mathrm{CT} \text { in the detection of }} \\
\text { HPT were } 94.1 \%, 97.9 \% \text { and } 92.4 \% \text {, } \\
\text { respectively. A single time-point } \\
\text { imaging could be associated with a } \\
\text { potential risk of missing lesions. }\end{array}$ \\
\hline 2020 & ${ }^{11} \mathrm{C}$ & $\begin{array}{l}\text { Ismail el al. [42] } \\
\quad 33228254\end{array}$ & $\mathrm{P}$ & 60 & 400 & $10 \pm 5$ & 1 & $\begin{array}{l}\text { Dual-tracer } \\
\text { SPECT/CT }\end{array}$ & Sensitivity & $\begin{array}{l}\text { At the patient level, sensitivities were } \\
0.98 \text { for dual-tracer subtraction } \\
\text { scintigraphy and } 1.00 \text { for }\left[{ }^{11} \mathrm{C}\right] \text { Choline } \\
\text { PET/CT. At the gland level, sensitivities } \\
\text { were } 0.88 \text { and } 0.87 \text {, respectively. }\end{array}$ \\
\hline
\end{tabular}

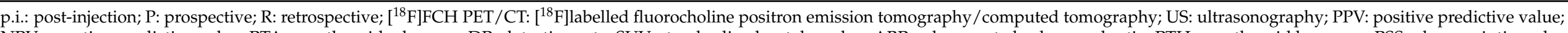

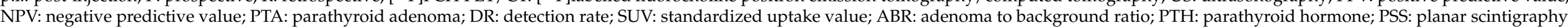
subtraction; ED: effective dose; RPH: radiopharmaceutical; A/T: adenoma/thyroid; LN/T: lymph node/ thyroid. 


\subsection{Positron Emission Tomography Procedure and Radiation Exposure}

As can be seen in Table 1, there was no standard dose administered. The mean dose was $2.5-3 \mathrm{MBq} / \mathrm{kg}$ in most of the studies but even lower doses did not appear to have an impact on performance.

A crucial point in parathyroid imaging is the correct timing of the post-injection acquisition that mainly differs in the studies according to radioisotope decay used (only 20 min half-life for ${ }^{11} \mathrm{C}$ compared with $110 \mathrm{~min}$ for ${ }^{18} \mathrm{~F}$ ). In 15 studies, the authors chose to perform only a single acquisition whereas a dual-phase protocol was the strategy of choice in 16 studies. In particular, a dynamic acquisition was performed in nine studies, an early static acquisition (set at $5 \mathrm{~min}$ in most cases) was taken by 12 authors, while a $60 \mathrm{~min}$ post-injection acquisition protocol was the most used timing set by the authors. Rep et al. were the only ones to perform a triple time-point protocol.

PET/CT was acquired in the supine position, extending the field of view (FOV) from the base of the skull to the diaphragm in order to include possible ectopic adenomas. None of the authors specified the preferred position of the arms. However, considering a head-neck district investigation, it is highly recommended to perform the scan with the arms down, hyperextending the neck, to avoid any attenuation by the body and reduction of the area visualization. In addition, Michaud et al. suggested extending the acquisition up to mid thighs in men in order not to miss potential prostate foci $[17,21]$.

Regarding radiation exposure, few results are available but promising. Rep et al. conducted a detailed analysis of $\left[{ }^{18} \mathrm{~F}\right] \mathrm{FCH} \mathrm{PET} / \mathrm{CT}$ radiation exposure in comparison with parathyroid dual-tracers' subtraction planar scintigraphy and dual-phase $\left[{ }^{99 \mathrm{~m}} \mathrm{Tc}\right] \mathrm{Tc}-\mathrm{MIBI}$ SPET/CT. The organ doses and the effective dose (ED) caused by radiopharmaceutical administration were calculated for each method. The median ED after radiopharmaceutical administration resulted in $7.4 \mathrm{mSv}$ (range 6.6-8.2) for parathyroid dual-tracers' subtraction planar scintigraphy, $5.4 \mathrm{mSv}$ (range 4.8-6.0) for dual-phase [ $\left.{ }^{99 \mathrm{~m}} \mathrm{Tc}\right] \mathrm{Tc}-\mathrm{MIBI}$ and $1.9 \mathrm{mSv}$ (range 1.8-3.0) for [ $\left.{ }^{18} \mathrm{~F}\right] \mathrm{FCH}$ PET. Moreover, the addition of the early and delayed CT, as part of the hybrid imaging procedures (SPET/CT vs. PET/CT), increased the ED of $26.4 \%$ and $42.2 \%$ for SPET/CT and PET/CT, respectively. The overall ED (radiopharmaceuti$\mathrm{cal}+$ early/delayed CT) resulted in lower $\left[{ }^{18} \mathrm{~F}\right] \mathrm{FCH}$ PET/CT than with $\left[{ }^{99 \mathrm{~m}} \mathrm{Tc}\right] \mathrm{Tc}-\mathrm{MIBI}$ SPECT/CT (2.8 mSv vs. $6.8 \mathrm{mSv})$ [26].

\subsection{Diagnostics Performance}

In Table 2 the detailed diagnostic performances of the main studies used for the comparison between nuclear medicine imaging methods are reported.

Table 2. Diagnostic performance of $\left[{ }^{18} \mathrm{~F}\right] \mathrm{FCH}$ PET/CT vs. parathyroid $\left[{ }^{99 \mathrm{~m}} \mathrm{Tc}\right] \mathrm{Tc}-\mathrm{MIBI}$ scintigraphy.

\begin{tabular}{|c|c|c|c|c|c|c|c|c|c|c|c|c|c|c|c|c|c|}
\hline & \multirow{3}{*}{ Author-PMID } & \multirow{3}{*}{ HPT } & \multicolumn{10}{|c|}{$\left[{ }^{18} \mathrm{~F}\right] \mathrm{FCH}$ PET/CT * } & \multicolumn{5}{|c|}{$\left[{ }^{99 m}\right.$ Tc]Tc-MIBI ** } \\
\hline & & & \multicolumn{5}{|c|}{ Per Lesion (\%) } & \multicolumn{5}{|c|}{ Per Patient (\%) } & \multirow[b]{2}{*}{ Sen } & \multirow[b]{2}{*}{ Spe } & \multirow[b]{2}{*}{ PPV } & \multirow[b]{2}{*}{ NPV } & \multirow[b]{2}{*}{ Acc } \\
\hline & & & Sen & Spe & PPV & NPV & Acc & Sen & Spe & PPV & NPV & Acc & & & & & \\
\hline \multirow{8}{*}{ 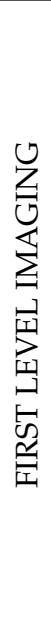 } & $\begin{array}{c}\text { Thanseer et al., } 2017 \\
\text { [22] }\end{array}$ & I & 100 & $\backslash$ & 96.3 & 1 & 96.3 & 100 & 1 & 92.8 & 1 & 92.8 & 80.7 & 1 & 97.7 & 1 & 79.6 \\
\hline & $\begin{array}{c}\text { Beheshti et al., } 2018 \\
\text { [11] }\end{array}$ & I & 93.7 & 96.0 & 90.2 & 97.4 & 95.3 & $\backslash$ & 1 & 1 & 1 & 1 & 60.8 & 98.5 & 94.1 & 86.3 & 87.7 \\
\hline & Araz et al., 2018 [13] & I & 96 & 100 & 100 & 93 & 97 & 1 & 1 & 1 & 1 & 1 & 78 & 100 & 100 & 70 & 86 \\
\hline & $\begin{array}{l}\text { Lezaic et al., } 2014 \\
\text { [16] }\end{array}$ & I & $\backslash$ & 1 & 1 & $\backslash$ & 1 & 92 & 100 & 100 & 96 & 98 & 64 & 100 & 100 & 85 & 88 \\
\hline & Rep et al., 2018 [26] & I & 97 & 99 & 1 & 1 & 1 & 1 & 1 & 1 & $\backslash$ & 1 & 64 & 96 & 1 & $\backslash$ & 1 \\
\hline & $\begin{array}{c}\text { Cuderman et al., } \\
2020 \text { [40] }\end{array}$ & $\mathrm{I}$ & 95.5 & 99.7 & 1 & $\backslash$ & 1 & 92 & 99.7 & 1 & 1 & 1 & 76 & 100 & 1 & $\backslash$ & 1 \\
\hline & $\begin{array}{l}\text { Bossert et al., } 2018 \\
\text { [27] }\end{array}$ & I & 88 & 1 & 1 & $\backslash$ & 1 & 1 & 1 & 1 & 1 & 1 & 17 & 1 & 1 & 1 & $\backslash$ \\
\hline & Rep et al., 2015 [19] & I & $\backslash$ & $\backslash$ & $\backslash$ & $\backslash$ & 1 & 93.6 & 98.2 & 96.7 & 96.4 & 96.5 & $\backslash$ & $\backslash$ & $\backslash$ & $\backslash$ & $\backslash$ \\
\hline
\end{tabular}


Table 2. Cont.

\begin{tabular}{|c|c|c|c|c|c|c|c|c|c|c|c|c|c|c|c|c|c|}
\hline & \multirow{3}{*}{ Author-PMID } & \multirow{3}{*}{ HPT } & \multicolumn{10}{|c|}{$\left[{ }^{18} \mathrm{~F}\right] \mathrm{FCH}$ PET/CT * } & \multicolumn{5}{|c|}{$\left[{ }^{99 m} \mathrm{Tc}\right] \mathrm{Tc}-\mathrm{MIBI}{ }^{* *}$} \\
\hline & & & \multirow[b]{2}{*}{ Sen } & \multicolumn{4}{|c|}{ Per Lesion (\%) } & \multicolumn{5}{|c|}{ Per Patient (\%) } & \multirow[b]{2}{*}{ Sen } & \multirow[b]{2}{*}{ Spe } & \multirow[b]{2}{*}{ PPV } & \multirow[b]{2}{*}{ NPV } & \multirow[b]{2}{*}{ Acc } \\
\hline & & & & Spe & PPV & NPV & Acc & Sen & Spe & PPV & NPV & Acc & & & & & \\
\hline \multirow{5}{*}{ 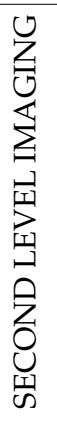 } & Quak et al., 2018 [29] & I & 91.3 & 1 & 87.5 & 1 & 1 & 90.5 & 1 & 86.4 & 1 & 1 & 1 & 1 & 1 & 1 & 1 \\
\hline & $\begin{array}{c}\text { Zajíčková et al., } 2018 \\
\text { [15] }\end{array}$ & I & 93 & 1 & 81 & $\backslash$ & $\backslash$ & 92 & $\backslash$ & 100 & 1 & 1 & 1 & 1 & $\backslash$ & 1 & $\backslash$ \\
\hline & $\begin{array}{l}\text { Uslu-Beşli et al., } \\
2020[41]\end{array}$ & I & 1 & 1 & 1 & 1 & 1 & 94.1 & 1 & 97.9 & $\backslash$ & 92.4 & 45.1 & $\backslash$ & 97.9 & $\backslash$ & 45.7 \\
\hline & $\begin{array}{l}\text { Michaud et al., } 2016 \\
\text { [21] }\end{array}$ & I; II & 96 & 56 & $\backslash$ & 1 & 1 & 1 & 1 & 1 & 1 & 1 & 83 & 56 & 1 & 1 & 1 \\
\hline & $\begin{array}{l}\text { Kluijfhout et al., } \\
2016 \text { [24] }\end{array}$ & I; III & 94.3 & 1 & 97.1 & 1 & 1 & 1 & 1 & 1 & 1 & 1 & 30 & 1 & 69.2 & 1 & 1 \\
\hline
\end{tabular}

HPT: hyperparathyroidism; I: primary hyperparathyroidism; II: secondary hyperparathyroidism; III: tertiary hyperparathyroidism; Sen: sensitivity; Spe: specificity; PPV: positive predictive value; NPV: negative predictive value; Acc: accuracy. ${ }^{*}$ values refer to [18F]FCH PET/CT acquisition at 60 min post-injection. ${ }^{* *}$ in cases of different [99mTc]Tc-MIBI protocols employed, the one with the highest performance values was reported.

For a correct evaluation of the choline PET/CT diagnostic performance and a reliable comparison with $\left[{ }^{99 \mathrm{~m}} \mathrm{Tc}\right] \mathrm{Tc}-\mathrm{MIBI}$ scintigraphy, only studies regarding $\left[{ }^{18} \mathrm{~F}\right]$ labeled choline PET/CT where both methods were employed as first level imaging were used for the analysis.

In this setting, $\left[{ }^{18} \mathrm{~F}\right] \mathrm{FCH}$ PET/CT showed a sensitivity(\%) of $96.4 \pm 2.3$ (median 96, range 93.7-100) and 95.0 \pm 4 (median 95.8, range 88-100) on per lesion and per patient analysis, respectively, while the sensitivity of parathyroid scintigraphy resulted in $62.9 \pm 21$ (median 64, range 17-80.7). This low mean value of [99m Tc]Tc-MIBI was probably related to the lowest sensitivity reported in one study (only 17\%) [27]. However, even excluding these data, the sensitivity of $\left[{ }^{18} \mathrm{~F}\right] \mathrm{FCH}$ PET/CT remained far higher (lesion-based: $96.4 \pm 2.3$, median 96, range 93.7-100; patient-based: $94.4 \pm 3.8$, median 92.8, range 92-100) than a traditional nuclear medicine technique (70.6 \pm 8.6 , median 70, range 60.8-80.7).

Regarding PPV (\%), [ $\left.{ }^{18} \mathrm{~F}\right] \mathrm{FCH}$ PET /CT demonstrated a lesion-based value of $95.5 \pm 4.9$ (median 96.3, range 90.2-100) and a patient-based value of $96.5 \pm 3.6$ (median 96.7, range 92.8-100) while [ $\left.{ }^{99 \mathrm{~m}} \mathrm{Tc}\right] \mathrm{Tc}-\mathrm{MIBI}$ PPV was $97.9 \pm 2.7$ (median 98.9, range 94.1-100).

The $\left[{ }^{18} \mathrm{~F}\right] \mathrm{FCH}$ PET/CT overall accuracy (\%) resulted in $96.2 \pm 0.8$ (median 96.3, range 95.3-97) and 95.7 \pm 2.6 (median 96.5, range 92.8-98) on a per lesion and per patient analysis, respectively, while the overall accuracy of parathyroid scintigraphy was $85.3 \pm 3.9$ (median 86.8 , range $79.6-88$ ).

Both imaging methods confirmed their high specificity (\%): lesion-based $98.6 \pm 1.8$ (median 99.3, range 96-100) and patient-based 99.3 \pm 0.9 (median 99.7, range 98.2-100) for $\left[{ }^{18} \mathrm{~F}\right] \mathrm{FCH}$ PET/CT and $98.8 \pm 1.7$ (median 100, range 96-100) for [ $\left.{ }^{99 \mathrm{~m}} \mathrm{Tc}\right] \mathrm{Tc}-\mathrm{MIBI}$.

The comparison suggested a better NPV (\%) of $\left[{ }^{18} \mathrm{~F}\right] \mathrm{FCH}$ PET/CT both on a per lesion (95.2 \pm 3.1 ; median 95.2) and a per patient (96.2 \pm 0.2 , median 96.2) analysis compared with [ $\left.{ }^{99 \mathrm{~m}} \mathrm{Tc}\right] \mathrm{Tc}-\mathrm{MIBI}(80.4 \pm 9.1$, median 80.5$)$.

The detection rate of $\left[{ }^{18} \mathrm{~F}\right] \mathrm{FCH}$ PET $/ \mathrm{CT}$ on 411 patients was $92 \%(91.9 \pm 8$, median 93.6, range 71-100).

\section{Discussion}

We firstly detected occasional findings on choline PET/CT performed for other reasons (i.e., Figure 2). In recent years interest has grown in the use of this multimodality imaging method in the preoperative localization of hyperfunctioning parathyroid glands.

Michaud et al. were one of the first to investigate the role of $\left[{ }^{18} \mathrm{~F}\right] \mathrm{FCH}$ PET/CT in HPT as second line imaging. In the two studies performed by the same group, a heterogeneous population of patients suffering from both primary and secondary HPT was considered, 

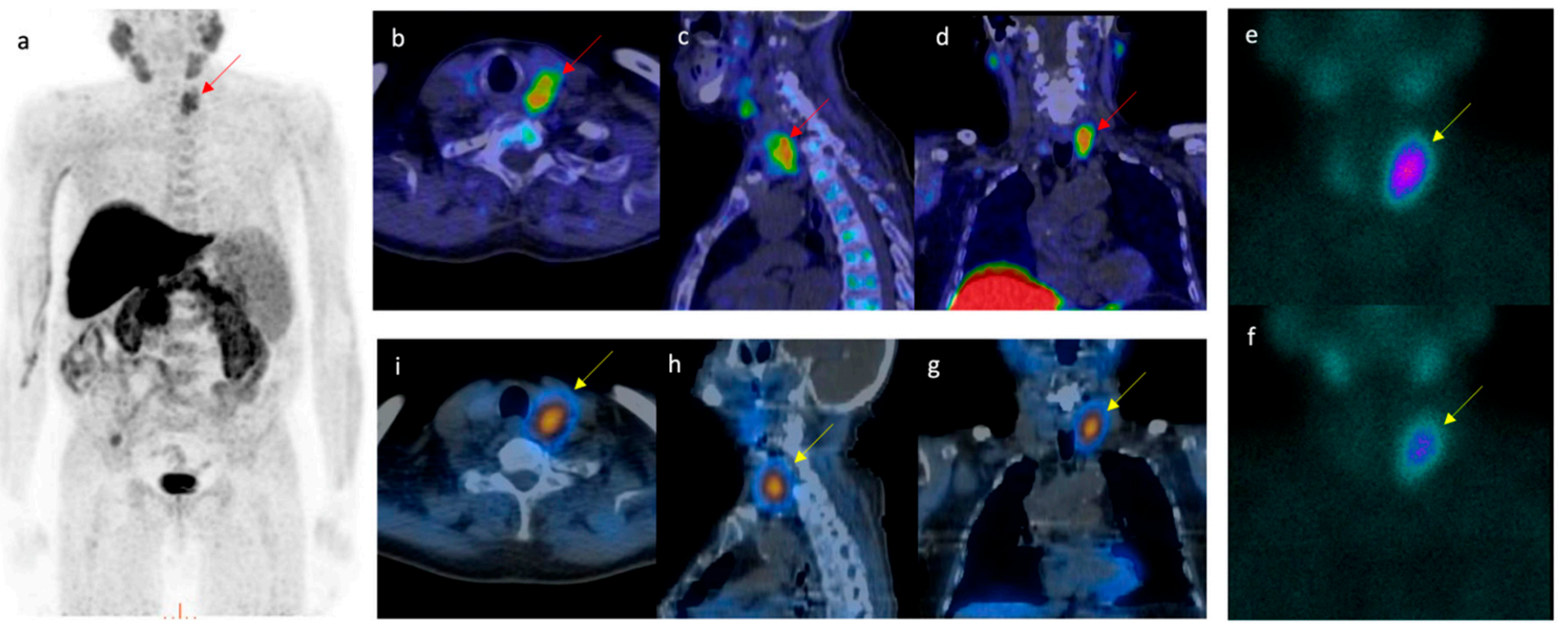

Figure 2. The clinical case of a 72-year-old man who underwent $\left[{ }^{18} \mathrm{~F}\right] \mathrm{FCH}$ PET/CT (a-d) revealed a focal $\left[{ }^{18} \mathrm{~F}\right] \mathrm{FCH}$ uptake posteriorly to the left thyroid lobe (red arrows), of probable parathyroid origin. The patient was directed to laboratory tests that showed a normal level of free triiodothyronine (FT3) (2.94 pg/mL, range 2.20-4.20) and free thyroxine (FT4) (12.4 pg/mL, range 8.10-17.1) as well as a normal thyroid-stimulating hormone (FSH) (1.34 mUI/L, range 0.3-3.6) but elevated PTH (761 pg/mL, range 14-72) and calcium levels (11.1 mg/dL, range 8.5-10.1). Consequently, the patient underwent $\left[{ }^{99 \mathrm{~m}} \mathrm{Tc}\right] \mathrm{Tc}-\mathrm{MIBI}$ parathyroid scintigraphy $(\mathbf{f}-\mathbf{i})$ according to a dual-phase protocol (e,f) integrated with single photon emission computed tomography/computed tomography (SPECT/CT) $(\mathbf{g}-\mathbf{i})$. $\left.{ }^{99 \mathrm{~m}} \mathrm{Tc}\right] \mathrm{Tc}-\mathrm{MIBI}$ identified the same focal area of increased uptake detected by $\left[{ }^{18} \mathrm{~F}\right] \mathrm{FCH}$ PET/CT (yellow arrows). Following the surgical removal, the pathology examination confirmed the presence of an atypical parathyroid adenoma (Ki67 < 10\%) with a post-surgical normalization of PTH and calcium levels. Based on the scientific evidence that proves the superiority of $\left[{ }^{18} \mathrm{~F}\right] \mathrm{FCH}$ PET/CT compared with $\left[{ }^{99 m} \mathrm{Tc}\right] \mathrm{Tc}-\mathrm{MIBI}$ in hyperparathyroidism, the patient could have avoided other diagnostic investigations, further radiation exposure and spared time for the cure.

Although used as a second line investigation when [ $\left.{ }^{99 \mathrm{~m}} \mathrm{Tc}\right] \mathrm{Tc}-\mathrm{MIBI}$ and US imaging were negative or inconclusive, the idea of using choline PET/CT as first line imaging is now supported by promising data.

In most articles of the available literature, choline is $\left[{ }^{18} \mathrm{~F}\right] l$ labeled, probably due to its favorable characteristics, with only four studies employing $\left[{ }^{11} \mathrm{C}\right]$ labeled choline.

In terms of sensitivity, both $\left[{ }^{11} \mathrm{C}\right]$ labeled and $\left[{ }^{18} \mathrm{~F}\right]$ labeled choline showed higher performance compared with traditional imaging methods. The results from a large sample of patients studied by Orevi et al. showed a higher sensitivity of $\left[{ }^{11} \mathrm{C}\right]$ Choline PET/CT $(92.3 \%)$ when compared with $\left.{ }^{99 \mathrm{~m}} \mathrm{Tc}\right] \mathrm{Tc}-\mathrm{MIBI}(88.5 \%)$ in parathyroid adenoma detection [18], up to $98 \%$ of sensitivity in other studies [38,42].

Different from $\left[{ }^{18} \mathrm{~F}\right]$ labeled choline, the use of $\left[{ }^{11} \mathrm{C}\right]$ labeled choline needs a shorter post-injection acquisition time. Noltes et al. set the optimal tracer uptake time at $20 \mathrm{~min}$ post-injection because adenoma choline uptake remains constant from $20 \mathrm{~min}$ onwards. Moreover, the same authors suggested a median administered dose of $6.3 \mathrm{MBq} / \mathrm{kg}$ and a scanning time for at least $5 \mathrm{~min}$ for $\left[{ }^{11} \mathrm{C}\right]$ Choline PET/CT [34].

Regarding $\left[{ }^{18} \mathrm{~F}\right]$ labeled choline, the analyzed data demonstrated the high sensitivity and overall accuracy of $\left[{ }^{18} \mathrm{~F}\right] \mathrm{FCH}$ PET/CT in locating hyperfunctioning parathyroid glands as a result of several factors.

First of all, the higher spatial resolution of PET/CT allows the identification of even smaller lesions [16]. Cuderman et al. showed that lesions with significantly smaller volumes and weights were correctly identified only on PET/CT imaging. The authors 
found that lesions with a median volume of $4.1 \mathrm{~cm}^{3}$ and a median weight of $0.5 \mathrm{~g}$ resulted as a true positive on PET/CT but as a false negative on conventional scintigraphy even if integrated with SPECT/CT [40]. Beheshti et al. confirmed this fact highlighting that the sizes of the parathyroid adenomas were significantly different between negative and positive [ ${ }^{99 \mathrm{~m}} \mathrm{Tc}$ ]Tc-MIBI/tetrofosmin SPECT/CT imaging [11].

A noteworthy aspect, directly correlated with a higher spatial resolution, concerns the ability of the $\left[{ }^{18} \mathrm{~F}\right] \mathrm{FCH} \mathrm{PET} / \mathrm{CT}$ to detect multiglandular pathology or parathyroid hyperplasia as well as adenomas. In fact, it is known that the diagnostic performance of $\left[{ }^{99 \mathrm{~m}} \mathrm{Tc}\right] \mathrm{Tc}-\mathrm{MIBI}$ scintigraphy is limited in the case of hyperplasia. The reason is not fully understood but a different mutation in the mitochondrial DNA of the adenoma might be the cause $[40,43,44]$.

Among the collected data, there were no studies that exclusively considered patients with multiglandular pathology or parathyroid hyperplasia. However, in a subanalysis conducted by Cuderman et al., $\left[{ }^{18} \mathrm{~F}\right] \mathrm{FCH}$ PET/CT showed a sensitivity of $88 \%$ in the detection of multiple parathyroid adenoma/hyperplasia compared with $34 \%, 22 \%, 22 \%$ and $44 \%$ of SPECT /CT, subtraction, dual-phase and combined protocols, respectively [40]. In another study, $\left[{ }^{18} \mathrm{~F}\right] \mathrm{FCH}$ PET/CT reached a sensitivity of $91 \%$ compared with $50 \%$ of conventional imaging [16].

Although there are no studies that specifically focused on ectopic parathyroid detection, $\left[{ }^{18} \mathrm{~F}\right] \mathrm{FCH}$ PET/CT has been shown to be superior to conventional imaging. Interestingly, Thanseer et al. reported in their series a case of an ectopic localization in a woman with recurrent HPT who had suffered an accidental implantation of parathyroid tissue in the left breast region $(\sim 0.8-0.4 \mathrm{~cm})$ following an endoscopic parathyroidectomy through a periareolar approach five years earlier. Only $\left[{ }^{18} \mathrm{~F}\right] \mathrm{FCH}$ PET/CT successfully localized the parathyroid adenoma in this rather unusual location [22].

In patients with persistent or recurrent primary HPT after surgery $\left[{ }^{18} \mathrm{~F}\right] \mathrm{FCH}$ yielded a $95.8 \%$ sensitivity when compared with [ $\left.{ }^{99 \mathrm{~m}} \mathrm{Tc}\right] \mathrm{Tc}-\mathrm{MIBI}(50.0 \%)$, US $(54.2 \%)$ and $4 \mathrm{DCeCT}$ (75.0\%) [7]. Sensitive preoperative imaging becomes essential for this setting of patients as well as in patients with a history of significant neck surgery such as a total thyroidectomy. In fact, neck surgery often leads to scar formation and/or anatomical modification, increases the risk of recurrent laryngeal nerve injury and is related to post-operative permanent hypoparathyroidism in up to $20 \%$ of cases, thus complicating the detection of abnormal parathyroid gland(s) $[33,45,46]$.

Other categories were also investigated. In patients with normocalcemic primary HPT, a milder form with a higher risk of complications $[47,48],\left[{ }^{18} \mathrm{~F}\right] \mathrm{FCH}$ PET/CT demonstrated a higher detection rate (71\%) than US (57\%) and [99m Tc]Tc-MIBI scintigraphy (6\%) [27].

Currently, primary HPT has been the most studied condition because surgical treatment is the standard of care and preoperative localization is essential. For this reason, the literature is poor in studies that exclusively analyzed patients with secondary HPT as well as with tertiary HPT. Only Xue et al. in their prospective study evaluated 17 patients with uremic HPT. The sensitivity, specificity, accuracy, PPV and NPV of $\left[{ }^{18} \mathrm{~F}\right] \mathrm{FCH}$ PET/CT were $84.13 \%, 100 \%, 86.49 \%, 100 \%$ and $52.38 \%$, respectively. In comparison, the corresponding values for $\left.{ }^{99 \mathrm{~m}} \mathrm{Tc}\right] \mathrm{Tc}-\mathrm{MIBI}$ SPECT $/ \mathrm{CT}$ were $63.49 \%, 90.91 \%, 67.57 \%$ and $30.0 \%$. In these patients, $\left[{ }^{18} \mathrm{~F}\right] \mathrm{FCH}$ PET /CT seemed to be able not only to provide additional information for surgery than traditional imaging methods but also to detect any bone complications that often occur in the tertiary form [36,49].

Finally, two studies compared $\left[{ }^{18} \mathrm{~F}\right] \mathrm{FCH}$ PET with $4 \mathrm{DCeCT}$, a method that provides both functional and anatomical information thanks to the addition of the fourth dimension consisting of changes in contrast attenuation over time [39]. It was shown that $\left[{ }^{18} \mathrm{~F}\right] \mathrm{FCH}$ PET /CT and 4DCeCT had quite similar detection rates ( $57 \%$ and $55 \%$, respectively) and sensitivities ( $81 \%$ and $74 \%$, respectively) and, consequently, integrated $\left[{ }^{18} \mathrm{~F}\right] \mathrm{FCH}$ PET $/ 4 \mathrm{DCeCT}$ could yield the highest reliability ( $73 \%$ detection rate and 100\% sensitivity) [32]. 
The results of choline PET in combination with magnetic resonance (MR) imaging are promising (90\% sensitivity, 100\% PPV in the Kluijfhout et al. study [24]) but more research and a larger sample size are needed $[28,35,50]$.

\subsection{Pitfalls}

The diagnostic performance of choline PET in HPT is affected by both false positive and false negative results.

False positives could be related to malignant disease such as differentiated thyroid carcinoma and/or metastatic lymph nodes as well as other benign conditions including thyroid nodules or inflammatory lymph nodes especially for ectopic locations [7,28].

In the setting of benign lesions, dual time scanning can help with a differential diagnosis; in the late phase, choline uptake decreases both in the thyroid gland parenchyma and inflammatory lymph nodes whereas it increases in parathyroid adenomas $[25,26,31]$. Similarly, Prabhu et al. reported that early dynamic imaging could also be helpful in differentiating between parathyroid adenomas and cervical reactive lymph nodes that might be confused with small adenomas/hyperplasic glands. The authors demonstrated that the adenoma/thyroid ratio was significantly higher than the lymph node/thyroid ratio ( $p=0.0117$ ) [30]. Not least, a high uptake of choline has been documented in oncocytic thyroid adenomas [51-53].

On the other hand, false negative findings could be related to very small parathyroid adenomas, particularly in a close vicinity to the thyroid gland [32], to the ectopic localization of the parathyroid gland, to multiglandular disease [7] or in cases of intrathyroidal atypical parathyroid adenoma, which is a rare entity with borderline pathological characteristics between adenoma and carcinoma [13,54].

In addition, in patients with autoimmune thyroid disease such as Hashimoto thyroiditis or Graves' disease a diffuse choline uptake in the thyroid gland can mask a possible parathyroid adenoma resulting in a false negative finding [3,55-57]. However, another study documented that the presence of autoimmune thyroid disease did not compromise the use of choline PET/CT from an accurate localization of parathyroid adenoma [15,58].

All of these pitfalls could complicate the correct localization of enlarged parathyroid glands either by US or [ ${ }^{99} \mathrm{~m}$ Tc]Tc-MIBI scintigraphy $[29,58,59]$. However, thanks to the above-mentioned advantages of choline PET/CT in terms of a higher spatial resolution, a better lesion-to-background ratio as well as the added value of semi-quantitative analysis, it overcomes traditional imaging in facing a few of these important issues.

\subsection{Semi-Quantitative Analysis and Biochemical Data Correlation}

As mentioned above, different protocols were studied with special reference to the semi-quantitative parameters.

Prabhu et al. supported the use of dynamic acquisition instead of delayed static imaging, demonstrating that both the maximum standardized uptake value (SUVmax) and the parathyroid/thyroid ratio ( $\mathrm{P} / \mathrm{T}$ ratio) were comparable in the two acquisition time protocols [30].

When comparing early and delayed static acquisitions, several authors observed a better lesion-to-background and lesion-to-thyroid contrast on late images but all lesions were visible at both phases $[16,17,21,31]$.

Other studies found an increase in the SUVmax of the lesion on late images, suggesting that a single late acquisition may be sufficient in patients with high PTH levels $[22,23,27]$.

In the only study considering a triple time-point protocol, Rep et al. found that the optimal scan time was at 60 min after the tracer injection and had a higher accuracy than early images and the same accuracy of images obtained at $120 \mathrm{~min}$ (diagnostic accuracies of $94.1 \%, 96.5 \%$ and $96.5 \%$ at 5, 60 and 120 min after injection, respectively) [19].

Considering that some lesions could be missed in one-phase acquisition, the dual time-point protocol seemed to be the optimal parathyroid study [31]. More studies are necessary to establish the role of dynamic/early static acquisition not only for comparison 
with the late images but also for the possibility of performing it as a single scan, reducing examination times especially for uncooperative patients.

Data related to semi-quantitative parameters of choline PET/CT are not uniform and a standardized cut-off does not exist to differentiate towards physiological and pathological parathyroid uptake. In fact, the SUVmax was similar in the case of true positive and false positive uptakes (mean value 4.5 vs. 3.1, respectively) [7]. In a few articles, parathyroid adenoma showed a higher SUVmax than hyperplasic glands (mean value 6.80 vs. 4.53 ) but the difference was not significant [11]. However, additional information could be obtained by comparing the parathyroid uptake with the background and/or the thyroid uptake [29]. The $\mathrm{P} / \mathrm{T}$ ratio ranged from 1.2 to 2.5 on average $[11,20,21]$.

A few authors investigated whether the SUVmax may be predictive of disease severity by exploring a possible correlation between the SUVmax values of hyperfunctioning parathyroid gland(s) and serum PTH, Ca, phosphorus (P) levels and bone mineral densitometry (BMD) results. In 2018, a retrospective study of 52 patients highlighted a strong positive correlation between the SUVmax and the PTH level as well as between the adenoma-to-background ratio and the PTH level on both late and early phases [25].

Morland et al. identified a significant association between $\left[{ }^{18} \mathrm{~F}\right] \mathrm{FCH}$ PET/CT and higher calcium levels; in their study, $\left[{ }^{18} \mathrm{~F}\right] \mathrm{FCH}$ PET/CT was performed during Cinacalcet treatment in $23 \%$ of patients [32]. Cinacalcet is a modulator of the calcium-sensing receptor strongly expressed on the surface of parathyroid cells that reduces serum calcium and PTH levels in patients for whom surgery is not clinically indicated or contraindicated. The authors found that Cinacalcet did not negatively impact the $\left[{ }^{18} \mathrm{~F}\right] \mathrm{FCH}$ PET/CT results. Rather, patients displaying positive $\left[{ }^{18} \mathrm{~F}\right] \mathrm{FCH} \mathrm{PET} / \mathrm{CT}$ tended to be more frequently under Cinacalcet treatment presumably because of higher calcium levels $[1,60,61]$. Interestingly, calcium was the only parameter that showed a significant association with positive findings on integrated [ $\left.{ }^{18} \mathrm{~F}\right] \mathrm{FCH}$ PET/4DCeCT [32].

The correlation between the SUVmax and densitometric results was also examined. Serum PTH levels were significantly higher and femoral/lumbar T values were lower in patients with an SUVmax greater than 4.4 [13]. Choline uptake seemed to be correlated with the molecular profile too; a significant correlation between the SUVratio and Ki67 expression and an inverse correlation between SUV parameters (SUVmax; SUVratio) and p53 expression was demonstrated [32].

At the time of writing this review, the phase III clinical trial APACH2 is ongoing [62]. As highlighted in this literature overview, the trial aims to demonstrate that the high diagnostic performance of $\left[{ }^{18} \mathrm{~F}\right] \mathrm{FCH} \mathrm{PET} / \mathrm{CT}$ could improve the outcome of patients, resulting in a saving in terms of total clinical care costs. Preliminary results are waited for to confirm the direction in the near future.

\section{Conclusions}

In conclusion, due to the high diagnostic value demonstrated by the reported data, choline PET could represent the ideal method to replace traditional imaging in the preoperative localization of hyperfunctioning parathyroid gland(s), demonstrating it to be a significantly more sensitive method in different patient settings than any conventional scintigraphic approach used.

Author Contributions: Conceptualization, C.F. and G.S.; methodology, C.F. writing-original draft preparation, G.S.; writing-review and editing, C.F. and P.M.; visualization, A.R.P.; supervision, A.S.; project administration, G.R. All authors have read and agreed to the published version of the manuscript. 
Funding: This research received no external funding.

Institutional Review Board Statement: Not applicable.

Informed Consent Statement: Not applicable.

Data Availability Statement: Not applicable.

Conflicts of Interest: The authors declare no conflict of interest.

\section{References}

1. Morland, D.; Lalire, P.; Deguelte, S.; Zalzali, M.; Richard, C.; Dejust, S.; Boulagnon, C.; Ly, S.; Papathanassiou, D.; Delemer, B. Added value of $18 \mathrm{~F}$-fluorocholine positron emission tomography-computed tomography in presurgical localization of hyperfunctioning parathyroid glands after dual tracer subtraction scintigraphy failure: A retrospective study of 47 patients. Medicine 2020, 99, e18681. [CrossRef]

2. Walker, M.D.; Silverberg, S.J. Primary hyperparathyroidism. Nat. Rev. Endocrinol. 2018, 14, 115-125. [CrossRef]

3. Kunstman, J.W.; Kirsch, J.D.; Mahajan, A.; Udelsman, R. Parathyroid localization and implications for clinical management. J. Clin. Endocrinol. Metab. 2013, 98, 902-912. [CrossRef] [PubMed]

4. Giordano, A.; Marozzi, P.; Meduri, G.; Ficola, U.; Calcagni, M.L.; Vaccaro, A.; Rubini, G.; Attard, M.; Li Puma, M.; Ricci, R.; et al. Quantitative comparison of technetium-99m tetrofosmin and thallium-201 images of the thyroid and abnormal parathyroid glands. Eur. J. Nucl. Med. 1999, 26, 907-911. [CrossRef]

5. Taieb, D.; Hindie, E.; Grassetto, G.; Colletti, P.M.; Rubello, D. Parathyroid scintigraphy: When, how, and why? A concise systematic review. Clin. Nucl. Med. 2012, 37, 568-574. [CrossRef]

6. Rubello, D.; Saladini, G.; Casara, D.; Borsato, N.; Toniato, A.; Piotto, A.; Bernante, P.; Pelizzo, M.R. Parathyroid imaging with pertechnetate plus perchlorate/MIBI subtraction scintigraphy: A fast and effective technique. Clin. Nucl. Med. 2000, $25,527-531$. [CrossRef] [PubMed]

7. Grimaldi, S.; Young, J.; Kamenicky, P.; Hartl, D.; Terroir, M.; Leboulleux, S.; Berdelou, A.; Hadoux, J.; Hescot, S.; Remy, H.; et al. Challenging pre-surgical localization of hyperfunctioning parathyroid glands in primary hyperparathyroidism: The added value of 18F-Fluorocholine PET/CT. Eur. J. Nucl. Med. Mol. Imaging 2018, 45, 1772-1780. [CrossRef]

8. Kannan, S.; Milas, M.; Neumann, D.; Parikh, R.T.; Siperstein, A.; Licata, A. Parathyroid nuclear scan. A focused review on the technical and biological factors affecting its outcome. Clin. Cases Miner. Bone Metab. 2014, 11, 25-30. [CrossRef]

9. Treglia, G.; Piccardo, A.; Imperiale, A.; Strobel, K.; Kaufmann, P.A.; Prior, J.O.; Giovanella, L. Diagnostic performance of choline PET for detection of hyperfunctioning parathyroid glands in hyperparathyroidism: A systematic review and meta-analysis. Eur. J. Nucl. Med. Mol. Imaging 2019, 46, 751-765. [CrossRef] [PubMed]

10. Lu, M.; Kjellin, H.; Fotouhi, O.; Lee, L.; Nilsson, I.L.; Haglund, F.; Höög, A.; Lehtiö, J.; Larsson, C. Molecular profiles of oxyphilic and chief cell parathyroid adenoma. Mol. Cell. Endocrinol. 2018, 470, 84-95. [CrossRef] [PubMed]

11. Beheshti, M.; Hehenwarter, L.; Paymani, Z.; Rendl, G.; Imamovic, L.; Rettenbacher, R.; Tsybrovskyy, O.; Langsteger, W.; Pirich, C. 18F-Fluorocholine PET/CT in the assessment of primary hyperparathyroidism compared with 99mTc-MIBI or 99mTc-tetrofosmin SPECT/CT: A prospective dual-centre study in 100 patients. Eur. J. Nucl. Med. Mol. Imaging 2018, 45, 1762-1771. [CrossRef] [PubMed]

12. Ishizuka, T.; Kajita, K.; Kamikubo, K.; Komaki, T.; Miura, K.; Nagao, S.; Nozawa, Y. Phospholipid/Ca2+-dependent Protein Kinase Activity in Human Parathyroid Adenoma. Endocrinol. Jpn. 1987, 34, 965-968. [CrossRef]

13. Araz, M.; Soydal, Ç.; Özkan, E.; Kır, M.K.; İbiş, E.; Güllü, S.; Erdoğan, M.F.; Emral, R.; Küçük, Ö.N. The efficacy of fluorine-18choline PET/CT in comparison with 99mTc-MIBI SPECT/CT in the localization of a hyperfunctioning parathyroid gland in primary hyperparathyroidism. Nucl. Med. Commun. 2018, 39, 989-994. [CrossRef]

14. Niccoli-Asabella, A.; Ferrari, C.; Antonica, F.; Scardapane, A.; Rubini, D.; Rubini, G. Unusual 18F-FDG PET/CT finding of an oxyphil parathyroid adenoma in a patient with Hodgkin's Lymphoma. Rev. Esp. Med. Nucl. Imagen Mol. 2014, 33, 370-373. [CrossRef] [PubMed]

15. Zajíčková, K.; Zogala, D.; Kubinyi, J. Parathyroid imaging by 18F-fluorocholine PET/CT in patients with primary hyperparathyroidism and inconclusive conventional methods: Clinico-pathological correlations. Physiol. Res. 2018, 67, S551-S557. [CrossRef]

16. Lezaic, L.; Rep, S.; Sever, M.J.; Kocjan, T.; Hocevar, M.; Fettich, J. 18F-Fluorocholine PET/CT for localization of hyperfunctioning parathyroid tissue in primary hyperparathyroidism: A pilot study. Eur. J. Nucl. Med. Mol. Imaging 2014, 41, 2083-2089. [CrossRef] [PubMed]

17. Michaud, L.; Burgess, A.; Huchet, V.; Lefèvre, M.; Tassart, M.; Ohnona, J.; Kerrou, K.; Balogova, S.; Talbot, J.N.; Périé, S. Is 18F-fluorocholine-positron emission tomography/ computerized tomography a new imaging tool for detecting hyperfunctioning parathyroid glands in primary or secondary hyperparathyroidism? J. Clin. Endocrinol. Metab. 2014, 99, 4531-4536. [CrossRef]

18. Orevi, M.; Freedman, N.; Mishani, E.; Bocher, M.; Jacobson, O.; Krausz, Y. Localization of parathyroid adenoma by 11C-Choline PET/CT preliminary results. Clin. Nucl. Med. 2014, 39, 1033-1038. [CrossRef]

19. Rep, S.; Lezaic, L.; Kocjan, T.; Pfeifer, M.; Sever, M.J.; Simoncic, U.; Tomse, P.; Hocevar, M. Optimal scan time for evaluation of parathyroid adenoma with [18F]-fluorocholine PET/CT. Radiol. Oncol. 2015, 49, 327-333. [CrossRef] 
20. Kluijfhout, W.P.; Vorselaars, W.M.C.M.; Van Den Berk, S.A.M.; Vriens, M.R.; Borel Rinkes, I.H.M.; Valk, G.D.; Van Dalen, T.; De Klerk, J.M.H.; De Keizer, B. Fluorine-18 fluorocholine PET-CT localizes hyperparathyroidism in patients with inconclusive conventional imaging: A multicenter study from the Netherlands. Nucl. Med. Commun. 2016, 37, 1246-1252. [CrossRef] [PubMed]

21. Michaud, L.; Balogova, S.; Burgess, A.; Ohnona, J.; Huchet, V.; Kerrou, K.; Lefèvre, M.; Tassart, M.; Montravers, F.; Périé, S.; et al. A pilot comparison of 18F-fluorocholine PET/CT, ultrasonography and 123I/99mTc-sestaMIBI dual-phase dual-isotope scintigraphy in the preoperative localization of hyperfunctioning parathyroid glands in primary or secondary hyperparathyroidism: Influence of. Medicine 2015, 94, e1701. [CrossRef]

22. Thanseer, N.; Bhadada, S.K.; Sood, A.; Mittal, B.R.; Behera, A.; Gorla, A.K.R.; Kalathoorakathu, R.R.; Singh, P.; Dahiya, D.; Saikia, U.N.; et al. Comparative Effectiveness of Ultrasonography, 99mTc-Sestamibi, and 18F-Fluorocholine PET/CT in Detecting Parathyroid Adenomas in Patients With Primary Hyperparathyroidism. Clin. Nucl. Med. 2017, 42, e491-e497. [CrossRef]

23. Hocevar, M.; Lezaic, L.; Rep, S.; Zaletel, K.; Kocjan, T.; Sever, M.J.; Zgajnar, J.; Peric, B. Focused parathyroidectomy without intraoperative parathormone testing is safe after pre-operative localization with 18F-Fluorocholine PET/CT. Eur. J. Surg. Oncol. 2017, 43, 133-137. [CrossRef] [PubMed]

24. Kluijfhout, W.P.; Pasternak, J.D.; Gosnell, J.E.; Shen, W.T.; Duh, Q.Y.; Vriens, M.R.; De Keizer, B.; Hope, T.A.; Glastonbury, C.M.; Pampaloni, M.H.; et al. 18F fluorocholine PET/MR imaging in patients with primary hyperparathyroidism and inconclusive conventional imaging: A prospective pilot study. Radiology 2017, 284, 460-467. [CrossRef]

25. Alharbi, A.A.; Alshehri, F.M.; Albatly, A.A.; Sah, B.R.; Schmid, C.; Huber, G.F.; Huellner, M.W. [18F] Fluorocholine Uptake of Parathyroid Adenoma Is Correlated with Parathyroid Hormone Level. Mol. Imaging Biol. 2018, 20, 857-867. [CrossRef]

26. Rep, S.; Hocevar, M.; Vaupotic, J.; Zdesar, U.; Zaletel, K.; Lezaic, L. 18F-choline PET/CT for parathyroid scintigraphy: Significantly lower radiation exposure of patients in comparison to conventional nuclear medicine imaging approaches. J. Radiol. Prot. 2018, 38, 343-356. [CrossRef]

27. Bossert, I.; Chytiris, S.; Hodolic, M.; Croce, L.; Mansi, L.; Chiovato, L.; Mariani, G.; Trifirò, G. PETC/CT with 18 F-Choline localizes hyperfunctioning parathyroid adenomas equally well in normocalcemic hyperparathyroidism as in overt hyperparathyroidism. J. Endocrinol. Investig. 2019, 42, 419-426. [CrossRef] [PubMed]

28. Huber, G.F.; Hüllner, M.; Schmid, C.; Brunner, A.; Sah, B.; Vetter, D.; Kaufmann, P.A.; von Schulthess, G.K. Benefit of18Ffluorocholine PET imaging in parathyroid surgery. Eur. Radiol. 2018, 28, 2700-2707. [CrossRef] [PubMed]

29. Quak, E.; Blanchard, D.; Houdu, B.; Le Roux, Y.; Ciappuccini, R.; Lireux, B.; de Raucourt, D.; Grellard, J.M.; Licaj, I.; Bardet, S.; et al. F18-choline PET/CT guided surgery in primary hyperparathyroidism when ultrasound and MIBI SPECT/CT are negative or inconclusive: The APACH1 study. Eur. J. Nucl. Med. Mol. Imaging 2018, 45, 658-666. [CrossRef]

30. Prabhu, M.; Kumari, G.; Damle, N.A.; Arora, G.; Kumar, P.; Kumar, R.; Tripathi, M.; Bal, C.; Khadgawat, R.; Kumar, C.; et al. Assessment of the role of early dynamic PET/CT with 18 F-fluorocholine in detection of parathyroid lesions in patients with primary hyperparathyroidism. Nucl. Med. Commun. 2018, 39, 1190-1196. [CrossRef]

31. Broos, W.A.M.; Wondergem, M.; van der Zant, F.M.; Knol, R.J.J. Dual-time-point 18F-fluorocholine PET/CT in parathyroid imaging. J. Nucl. Med. 2019, 60, 1605-1610. [CrossRef] [PubMed]

32. Piccardo, A.; Trimboli, P.; Rutigliani, M.; Puntoni, M.; Foppiani, L.; Bacigalupo, L.; Crescenzi, A.; Bottoni, G.; Treglia, G.; Paparo, F.; et al. Additional value of integrated 18 F-choline PET/4D contrast-enhanced CT in the localization of hyperfunctioning parathyroid glands and correlation with molecular profile. Eur. J. Nucl. Med. Mol. Imaging 2019, 46, 766-775. [CrossRef]

33. Amadou, C.; Bera, G.; Ezziane, M.; Chami, L.; Delbot, T.; Rouxel, A.; Leban, M.; Herve, G.; Menegaux, F.; Leenhardt, L.; et al. 18F-Fluorocholine PET/CT and Parathyroid 4D Computed Tomography for Primary Hyperparathyroidism: The Challenge of Reoperative Patients. World J. Surg. 2019, 43, 1232-1242. [CrossRef] [PubMed]

34. Noltes, M.E.; Kruijff, S.; Noordzij, W.; Telenga, E.D.; Vállez García, D.; Trofimiuk-Müldner, M.; Opalińska, M.; HubalewskaDydejczyk, A.; Luurtsema, G.; Dierckx, R.A.J.O.; et al. Optimization of parathyroid 11C-choline PET protocol for localization of parathyroid adenomas in patients with primary hyperparathyroidism. EJNMMI Res. 2019, 9, 1-10. [CrossRef] [PubMed]

35. Khafif, A.; Masalha, M.; Landsberg, R.; Domachevsky, L.; Bernstine, H.; Groshar, D.; Azoulay, O.; Lockman, Y. The role of F18-fluorocholine positron emission tomography/magnetic resonance imaging in localizing parathyroid adenomas. Eur. Arch. Oto Rhino Laryngol. 2019, 276, 1509-1516. [CrossRef] [PubMed]

36. Xue, Y.; Li, W.; Xia, Z.; Lei, C.; Cao, Y.; Wang, Z.; Pang, H. The role of 18F-FCH PET/CT in patients with uremic hyperparathyroidism compared with 99mTc-sestaMIBI SPECT/CT and ultrasonography. EJNMMI Res. 2019, 9, 1-8. [CrossRef]

37. Broos, W.A.M.; Wondergem, M.; Knol, R.J.J.; van der Zant, F.M. Parathyroid imaging with 18F-fluorocholine PET/CT as a first-line imaging modality in primary hyperparathyroidism: A retrospective cohort study. EJNMMI Res. 2019, 9, 1-7. [CrossRef] [PubMed]

38. Liu, Y.; Dang, Y.; Huo, L.; Hu, Y.; Wang, O.; Liu, H.; Chang, X.; Liu, Y.; Xing, X.; Li, F.; et al. Preoperative Localization of Adenomas in Primary Hyperparathyroidism: The Value of 11C-Choline PET/CT in Patients with Negative or Discordant Findings on Ultrasonography and 99mTc-Sestamibi SPECT/CT. J. Nucl. Med. 2020, 61, 584-589. [CrossRef] 
39. Pretet, V.; Rotania, M.; Helali, M.; Ignat, M.; Vix, M.; Imperiale, A. 18F-Fluorocholine PET and Multiphase CT Integrated in Dual Modality PET/4D-CT for Preoperative Evaluation of Primary Hyperparathyroidism. J. Clin. Med. 2020, 9, 2005. [CrossRef] [PubMed]

40. Cuderman, A.; Senica, K.; Rep, S.; Hocevar, M.; Kocjan, T.; Sever, M.J.; Zaletel, K.; Lezaic, L. 18F-Fluorocholine PET/CT in Primary Hyperparathyroidism: Superior Diagnostic Performance to Conventional Scintigraphic Imaging for Localization of Hyperfunctioning Parathyroid Glands. J. Nucl. Med. 2020, 61, 577-583. [CrossRef]

41. Uslu-Beşli, L.; Sonmezoglu, K.; Teksoz, S.; Akgun, E.; Karayel, E.; Pehlivanoglu, H.; Khosroshahi, B.R.; Ocak, M.; Kabasakal, L.; Sager, S.; et al. Performance of $\mathrm{f}-18$ fluorocholine PET/CT for detection of hyperfunctioning parathyroid tissue in patients with elevated parathyroid hormone levels and negative or discrepant results in conventional imaging. Korean J. Radiol. 2020, 21, 236-247. [CrossRef] 
42. Ismail, A.; Christensen, J.W.; Krakauer, M.; Søndergaard, S.B.; Zerahn, B.; Nygaard, B.; Bennedbæk, F.N.; Kristensen, B.; Jensen, L.T. 11C-Choline PET/CT vs. 99mTc-MIBI/123Iodide Subtraction SPECT/CT for Preoperative Detection of Abnormal Parathyroid Glands in Primary Hyperparathyroidism: A Prospective, Single-Centre Clinical Trial in 60 Patients. Diagnostics 2020, 10, 975. [CrossRef]

43. Costa-Guda, J.; Tokura, T.; Roth, S.I.; Arnold, A. Mitochondrial DNA mutations in oxyphilic and chief cell parathyroid adenomas. BMC Endocr. Disord. 2007, 7, 8. [CrossRef]

44. Tse, L.L.Y.; Chan, J.K.C. Thyroid and Parathyroid. In Modern Surgical Pathology; Elsevier Inc.: Amsterdam, The Netherlands, 2009; Volume 2, pp. 1597-1685. ISBN 9781416039662.

45. Karakas, E.; Müller, H.H.; Schlosshauer, T.; Rothmund, M.; Bartsch, D.K. Reoperations for primary hyperparathyroidismImprovement of outcome over two decades. Langenbeck's Arch. Surg. 2013, 398, 99-106. [CrossRef] [PubMed]

46. Parikh, P.P.; Farra, J.C.; Allan, B.J.; Lew, J.I. Long-term effectiveness of localization studies and intraoperative parathormone monitoring in patients undergoing reoperative parathyroidectomy for persistent or recurrent hyperparathyroidism. Am. J. Surg. 2015, 210, 117-122. [CrossRef] [PubMed]

47. Chen, G.; Xue, Y.; Zhang, Q.; Xue, T.; Yao, J.; Huang, H.; Liang, J.; Li, L.; Lin, W.; Lin, L.; et al. Is normocalcemic primary hyperparathyroidism harmful or harmless? J. Clin. Endocrinol. Metab. 2015, 100, 2420-2424. [CrossRef]

48. Lowe, H.; McMahon, D.J.; Rubin, M.R.; Bilezikian, J.P.; Silverberg, S.J. Normocalcemic primary hyperparathyroidism: Further characterization of a new clinical phenotype. J. Clin. Endocrinol. Metab. 2007, 92, 3001-3005. [CrossRef] [PubMed]

49. Ferrari, C.; Lavelli, V.; Santo, G.; Frugis, M.T.; Iuele, F.; Rubini, G.; Sardaro, A. 18F-Fluorocholine PET/CT, Tc-99m-MIBI and TC-99m-MDP SPECT/CT in Tertiary Hyperparathyroidism with Renal Osteodystrophy. Diagnostics 2020, 10, 851. [CrossRef]

50. Evangelista, L.; Ravelli, I.; Magnani, F.; Iacobone, M.; Giraudo, C.; Camozzi, V.; Spimpolo, A.; Cecchin, D. 18F-choline PET/CT and PET/MRI in primary and recurrent hyperparathyroidism: A systematic review of the literature. Ann. Nucl. Med. 2020, 34, 601-619. [CrossRef]

51. Vellani, C.; Hodolič, M.; Chytiris, S.; Trifirò, G.; Rubello, D.; Colletti, P.M. Early and Delayed 18F-FCH PET/CT Imaging in Parathyroid Adenomas. Clin. Nucl. Med. 2017, 42, 143-144. [CrossRef]

52. Oprea-Lager, D.E.; Vincent, A.D.; van Moorselaar, R.J.A.; Gerritsen, W.R.; van den Eertwegh, A.J.M.; Eriksson, J.; Boellaard, R.; Hoekstra, O.S. Dual-Phase PET-CT to Differentiate [18F] Fluoromethylcholine Uptake in Reactive and Malignant Lymph Nodes in Patients with Prostate Cancer. PLoS ONE 2012, 7, e48430. [CrossRef]

53. Aziz, A.L.; Courbon, F.; Dierickx, L.O.; Pascal, P.; Zerdoud, S. Oncocytic adenoma of thyroid incidentally detected by 18Ffluorocholine PET/CT. J. Nucl. Med. Technol. 2015, 43, 133-134. [CrossRef] [PubMed]

54. Carlson, D. Parathyroid pathology hyperparathyroidism and parathyroid tumors. Arch. Pathol. Lab. Med. 2010, 134, 1639-1644. [CrossRef] [PubMed]

55. Kuzminski, S.J.; Sosa, J.A.; Hoang, J.K. Update in Parathyroid Imaging. Magn. Reson. Imaging Clin. N. Am. 2018, 26, 151-166. [CrossRef]

56. Krátký, J.; Vítková, H.; Bartáková, J.; Telička, Z.; Antošová, M.; Límanová, Z.; Jiskra, J. Thyroid nodules: Pathophysiological insight on oncogenesis and novel diagnostic techniques. Physiol. Res. 2014, 63, S263-S275. [CrossRef]

57. Boi, F.; Lombardo, C.; Cocco, M.C.; Piga, M.; Serra, A.; Lai, M.L.; Calò, P.G.; Nicolosi, A.; Mariotti, S. Thyroid diseases cause mismatch between MIBI scan and neck ultrasound in the diagnosis of hyperfunctioning parathyroids: Usefulness of FNA-PTH assay. Eur. J. Endocrinol. 2013, 168, 49-58. [CrossRef]

58. Fischli, S.; Suter-Widmer, I.; Nguyen, B.T.; Müller, W.; Metzger, J.; Strobel, K.; Grünig, H.; Henzen, C. The significance of 18Ffluorocholine-PET/CT as localizing imaging technique in patients with primary hyperparathyroidism and negative conventional imaging. Front. Endocrinol. 2018, 8, 380. [CrossRef]

59. Soelberg, K.K.; Bonnema, S.J.; Brix, T.H.; Hegedüs, L. Risk of malignancy in thyroid incidentalomas detected by 18Ffluorodeoxyglucose positron emission tomography: A systematic review. Thyroid 2012, 22, 918-925. [CrossRef]

60. Peacock, M.; Bilezikian, J.P.; Klassen, P.S.; Guo, M.D.; Turner, S.A.; Shoback, D. Cinacalcet hydrochloride maintains long-term normocalcemia in patients with primary hyperparathyroidism. J. Clin. Endocrinol. Metab. 2005, 90, 135-141. [CrossRef]

61. Marcocci, C.; Chanson, P.; Shoback, D.; Bilezikian, J.; Fernandez-Cruz, L.; Orgiazzi, J.; Henzen, C.; Cheng, S.; Sterling, L.R.; $\mathrm{Lu}$, J.; et al. Cinacalcet reduces serum calcium concentrations in patients with intractable primary hyperparathyroidism. J. Clin. Endocrinol. Metab. 2009, 94, 2766-2772. [CrossRef] [PubMed]

62. Quak, E.; Lasne Cardon, A.; Ciappuccini, R.; Lasnon, C.; Bastit, V.; Le Henaff, V.; Lireux, B.; Foucras, G.; Jaudet, C.; Berchi, C.; et al. Upfront F18-choline PET/CT versus Tc99m-sestaMIBI SPECT/CT guided surgery in primary hyperparathyroidism: The randomized phase III diagnostic trial APACH2. BMC Endocr. Disord. 2021, 21, 1-17. [CrossRef] [PubMed] 